Georgia State University

ScholarWorks @ Georgia State University

3-1-2019

\title{
Identifying and Disentangling the Impact of Fiscal Decentralization on Economic Growth
}

Gustavo Canavire-Bacarreza

Inter-American Development Bank, gcanavire@gmail.com

Jorge Martinez-Vazquez

Georgia State University, jorgemartinez@gsu.edu

Bauyrzhan Yedgenov

Georgia State University, byedgenov1@student.gsu.edu

Follow this and additional works at: https://scholarworks.gsu.edu/icepp

\section{Recommended Citation}

Canavire-Bacarreza, Gustavo; Martinez-Vazquez, Jorge; and Yedgenov, Bauyrzhan, "Identifying and Disentangling the Impact of Fiscal Decentralization on Economic Growth" (2019). ICEPP Working Papers. 151.

https://scholarworks.gsu.edu/icepp/151

This Article is brought to you for free and open access by the International Center for Public Policy at ScholarWorks @ Georgia State University. It has been accepted for inclusion in ICEPP Working Papers by an authorized administrator of ScholarWorks @ Georgia State University. For more information, please contact scholarworks@gsu.edu. 
Working Paper 19-03

March 2019

Identifying and Disentangling the Impact of Fiscal Decentralization on Economic Growth

Gustavo Canavire-Bacarreza

Jorge Martinez-Vazquez

Bauyrzhan Yedgenov 



\title{
$\underset{\begin{array}{c}\text { GeorgatStet } \\ \text { University }\end{array}}{\int \text { ANDREW YOUNG SCHOOL }_{\text {OF POLICY STUDIES }}}$
}

International Center for Public Policy

Working Paper 19-03

\section{Identifying and Disentangling the Impact of Fiscal Decentralization on Economic Growth}

\author{
Gustavo Canavire-Bacarreza \\ Jorge Martinez-Vazquez \\ Bauyrzhan Yedgenov
}

March

2019

International Center for Public Policy

Andrew Young School of Policy Studies

Georgia State University

Atlanta, Georgia 30303

United States of America

Phone: (404) 413-0235

Fax: (404) 651-4449

Email: paulbenson@gsu.edu

Website: http://icepp.gsu.edu/

Copyright 2019, the Andrew Young School of Policy Studies, Georgia State University. No part of the material protected by this copyright notice may be reproduced or utilized in any form or by any means without prior written permission from the copyright owner. 


\section{$\underset{\substack{\text { Georgatsate } \\ \text { University }}}{\iint_{\text {OF POLICY STUDIES }}} \mid \frac{\text { ANDREW YOUNG SCHOOL }}{\mid}$}

\section{International Center for Public Policy Andrew Young School of Policy Studies}

The Andrew Young School of Policy Studies was established at Georgia State University with the objective of promoting excellence in the design, implementation, and evaluation of public policy. In addition to two academic departments (economics and public administration), the Andrew Young School houses seven leading research centers and policy programs, including the International Center for Public Policy.

The mission of the International Center for Public Policy (ICePP) at the Andrew Young School of Policy Studies is to provide academic and professional training, applied research, and technical assistance in support of sound public policy and sustainable economic growth in developing and transitional economies.

ICePP is recognized worldwide for its efforts in support of economic and public policy reforms through technical assistance and training around the world. This reputation has been built serving a diverse client base, including the World Bank, the U.S. Agency for International Development (USAID), the United Nations Development Programme (UNDP), finance ministries, government organizations, legislative bodies, and private sector institutions.

The success of ICePP reflects the breadth and depth of its in-house technical expertise. The Andrew Young School's faculty are leading experts in economics and public policy and have authored books, published in major academic and technical journals, and have extensive experience in designing and implementing technical assistance and training programs. Andrew Young School faculty have been active in policy reform in over 40 countries around the world. Our technical assistance strategy is not merely to provide technical prescriptions for policy reform, but to engage in a collaborative effort with host governments and donor agencies to identify and analyze the issues at hand, arrive at policy solutions, and implement reforms.

ICePP specializes in four broad policy areas:

- Fiscal policy (including tax reforms, public expenditure reviews, tax administration reform)

- Fiscal decentralization (including decentralization reforms, design of intergovernmental transfer systems, urban government finance)

- Budgeting and fiscal management (including local government budgeting, performancebased budgeting, capital budgeting, multi-year budgeting)

- Economic analysis and revenue forecasting (including micro-simulation, time series forecasting)

For more information about our technical assistance activities and training programs, please visit our website at http://icepp.gsu.edu or contact us by email at paulbenson@gsu.edu. 


\title{
Identifying and Disentangling the Impact of Fiscal Decentralization on Economic Growth ${ }^{*}$
}

\author{
Gustavo Canavire-Bacarreza ${ }^{\dagger}$ Jorge Martinez-Vazquez ${ }^{\ddagger}$ Bauyrzhan Yedgenov ${ }^{\ddagger}$
}

March 2019

\begin{abstract}
This paper revisits the relationship between fiscal decentralization and economic growth by addressing the endogeneity issue stemming from reverse causality and unobserved factors that has plagued the extensive previous literature on this subject. In our approach, we use the Geographic Fragmentation Index (GFI) and country size as instrumental variables, which we argue are strong and consistent instruments for fiscal decentralization. Empirically, we find that indeed both instruments are strong and valid in the first stage of estimation and that on average, a 10-percent increase in subnational expenditure or revenue shares - the conventional measures of decentralization - will increase GDP per capita growth by approximately 0.4 percentage points; however, the results differ for developed versus developing countries.
\end{abstract}

JEL Classification: O47, H77, E62

Keywords: Fiscal Decentralization, Geography, Economic Growth

\footnotetext{
* The opinions in this paper are solely those of the authors and do not necessarily reflect the opinion of the Inter-American Development Bank or its Board of Directors, nor of the countries that they represent.

$\dagger$ Inter-American Development Bank, email: gcanavire@ gmail.com

* International Center for Public Policy, Georgia State University, emails: jorgemartinez@gsu.edu;

byedgenov1@student.gsu.edu
} 


\section{Introduction}

The last three decades have witnessed an unprecedented increase in decentralization reforms, not only in developed countries, some of which had been historically decentralized, but also in developing and transitional countries, the latter especially moving away from the perceived failings of centralized socialist planning (Drucker, 1993; World Bank, 1996). ${ }^{1}$ In fact, according to data gathered by Garman et al. (2001), more than 80 percent of the 75 developing countries analyzed were undergoing some decentralization of authority by the beginning of the millennium. In the case of developed countries, the index of regional authority computed by Hooghe et al. (2010) for 42 democracies and semi-democracies reveals that 70 percent of the countries have decentralized since 1950 .

There are several reasons for this trend. For most countries, fiscal decentralization has been a means for increasing the efficiency of government service delivery to achieve higher economic growth, while other nations have embraced decentralization following discontent with failed central planning practices, especially the former Soviet countries. In other cases, decentralization has been used to appease the eruption of conflict and to maintain territorial unity (Martinez-Vazquez et al., 2016). As initially argued by Oates (1974), fiscally decentralized systems can be more efficient at providing public services at a local level, resulting in better social conditions and higher economic growth. A vast empirical literature has followed over the last decades with the goal of determining the actual effects of decentralization on economic growth. A quick scholarly search reveals over 60 published works on the impact of fiscal

\footnotetext{
${ }^{1}$ Even many contemporary communist regimes, such as China or Vietnam, have moved significantly toward fiscally decentralized systems at the same time that they have adopted more market-oriented economic institutions.
} 
decentralization on various economic indicators, with more than half of those focusing on economic growth (Martinez-Vazquez et al. 2016, Baskaran and Feld, 2013).

However, virtually all the previous papers in this vast literature suffer from a fundamental identification problem: economic growth is impacted by decentralization, but decentralization can also be affected by economic growth (Jilek, 2018). This presence of endogeneity continues to call into question the received wisdom regarding the causal effect of fiscal decentralization on growth that has been embraced by decentralized governance in recent decades. ${ }^{2}$

In this paper, we offer a solution to this identification problem. We use as instrumental variables the Geographic Fragmentation Index (GFI), a measure of a country's elevation heterogeneity, and country size. These variables are jointly highly correlated with fiscal decentralization and neither directly nor indirectly correlated with economic growth, except through fiscal decentralization. The basic idea behind this relationship is that geographic conditions, such as significant variations in elevation or country size, have long influenced the degree of heterogeneity in tastes and preferences for local and regional public goods and services in countries around the world. This persistence of heterogeneity in demand for public services eventually leads to heightened demand for fiscal autonomy and fiscal decentralization. Even though the effect of geography can be weakened by migration and infrastructure development, the overall effect would appear to endure over time due to the assimilation of newcomers. A more detailed discussion follows in the next sections.

\footnotetext{
${ }^{2}$ The focus of this paper is on decentralization and economic growth. However, there is also a large literature on the impact of decentralization on other variables of interest, such as macroeconomic stability, income distribution or corruption. In most cases, however, the same identification issue of endogeneity is present.
} 
Empirically, we find that both of the geographical instrumental variables perform as strong valid instruments for fiscal decentralization and that fiscal decentralization has a significant positive impact on economic growth, especially in the case of developed countries. Our findings show that a 10-percent increase in the share of subnational expenditure in total general government expenditures will increase GDP per capita growth by 0.42 percentage points, while a 10-percent increase in the share of subnational revenue in total general government revenue will increase the GDP per capita growth by 0.41 percentage points. Overall, these findings support the side of the literature that has found a positive impact of fiscal decentralization on economic growth (Yilmaz, 1999; Ebel and Yilmaz, 2002; Thiessen, 2003; Breuss and Eller, 2004; Iimi, 2005). However, our estimated coefficients are significantly smaller than the average coefficient of 0.6 reported in past studies that found a positive impact (Iimi, 2005), or the coefficients above 1 usually reported in single country studies. In our empirical analysis, we further partition the sample into developed and developing countries. For the subsample of developed countries, we find statistically significant coefficients for expenditure and revenue decentralization of 0.25 and 0.52 , respectively, which are larger than the average magnitude of 0.12-0.15 reported in past studies for this group of countries (Thiessen, 2003). However, for developing countries, the coefficients are not significant at the 10-percent confidence level, a finding that supports another strand of literature related to this other group of countries (Woller and Phillips, 1998).

The rest of the paper is organized as follows. Section 2 presents a brief review of the relevant literature, Section 3 examines the validity of geography as an instrument, Section 4 describes the data and the empirical strategy, Section 5 presents the results, and Section 6 concludes the paper. 


\section{Literature review}

There is an extensive body of literature spanning decades of both a theoretical and empirical nature on the impact of fiscal decentralization on growth and other economic indicators. Although not speaking directly to the issue of growth, the traditional "firstgeneration" literature pioneered by Oates (1972) that emphasized associated efficiency gains, and even Brennan and Buchanan's (1980) argument of decentralization containing an inefficient Leviathan, hint at the potential growth-enhancing role of fiscal decentralization. On the other hand, the "second-generation" theory of fiscal decentralization developed by Qian and Weingast (1997) and others, which emphasizes the role of government officials as self-interested agent, hints at the possibility that the outcomes of decentralization may not always be growth enhancing.

The literature that has directly focused on the relationship between fiscal decentralization and economic growth has been mostly empirical, and the findings have varied significantly in direction and size. The large share of this research has been based on cross-country studies, especially developed countries due to the higher quality of available data, ${ }^{3}$ but there has also been a significant number of country case studies, especially across provinces in China. ${ }^{4}$ Early on, Martinez-Vazquez and McNab (2003) concluded that there was no empirical consensus on the effect of fiscal decentralization on economic growth, and that conclusion was still reaffirmed more recently by Baskaran et al. (2017). Although there are several potential reasons for this lack of consensus on the empirical findings, one serious untreated problem that is common to most of

\footnotetext{
${ }^{3}$ See Oates (1995), Yilmaz (1999), Gemmel, Kneller, and Sanz (2013), Davoodi and Zou (1998), Woller and Phillips (1998), Ezcurra and Rodriguez-Pose (2011), Baskaran and Feld (2013), Blöchliger and Akgun (2018), and Wang (2018).

${ }^{4}$ See Qiao et al. (2008), Feld et al. (2004), Akai and Sakata (2002), Zhang and Zou (1998, 2001), Xie et al. (1999), Lin and Liu (2000), Thiessen (2003), and Dign et al. (2019).
} 
this past literature has been the presence of endogeneity between fiscal decentralization and economic growth (Martinez-Vazquez et al. 2016).

However, this endogeneity problem has not always gone unnoticed. Some studies have used initial values of the independent variables to address endogeneity (Akai and Sakata, 2002; Bodman et al., 2009), while other studies have used lagged independent variables as IVs (Iimi, 2005; Enikopolov and Zhuravskaya, 2007; Gemmel, Kneller and Sanz, 2013). While a plausible solution, this being a complex policy reform issue, fiscal decentralization institutions tend to be quite stable over time and therefore susceptible to auto-correlation, which means that initial or lagged values are likely to be just as endogenous with regard to economic growth.

Other studies have used a variety of IVs to address the issue of endogeneity. For example, Perez-Sebastian and Raveh (2013) use lagged democracy as an instrument, and La Porta et al. (1999) use the country's legal origin. Although those instruments are appealing, both of these variables are highly correlated with economic growth itself, even when using their lagged values, and therefore cannot truly satisfy the exclusion restriction. Closer to the approach suggested in this paper, Enikopolov and Zhuravskaya (2007) use land area as an IV as part of a robustness test. However, they only report their first stage results where land area and its interactions with other explanatory variables usually take insignificant coefficients. Most recently, Ligthart and Oudheusden (2017) used a composite of several country characteristics, including legal system origin, country size, federal system and geographical position, as an IV. The authors employ an instrumental variable in the Bartik spirit, which, for a country, is a weighted average of the fiscal decentralization measures of all the other countries in the sample, where the weights are determined by the similarity of these countries to that particular country. They argue that countries with similarities with regard to these characteristics experience a 
similar degree and process of fiscal decentralization. While this IV sounds promising, the authors admit that they interpolate missing fiscal decentralization values and use these characteristics as a weight, rather than as IVs themselves.

A fair conclusion to be drawn from this literature is that the causal effect of fiscal decentralization on economic growth remains an open question. Beyond the many cases of contradictory findings, practically all of the previous empirical work on the question suffers from the potential endogeneity problem due to reverse causality and omitted variable bias.

The main objective and contribution of this paper is to address the issue of endogeneity between fiscal decentralization and economic growth using various dimensions of geography as instrumental variables for fiscal decentralization. The validity of geography as an IV for fiscal decentralization is carefully scrutinized but ultimately supported by our analysis. As we describe in the next section, unlike previous attempts using an IV approach, our geography-based IVs are exogenous and satisfy the exclusion restriction, including over time. Our estimated results using this IV approach show to what extent the findings in the previous literature concerning fiscal decentralization and growth need to be reassessed. These findings are valuable because beyond the issue of economic growth, there are several other significant bodies of literature that examine the impact of fiscal decentralization on other important economic dimensions, such as macroeconomic stability or the extent of corruption, which potentially suffer from the same endogeneity issue vis-à-vis fiscal decentralization. The instrumental variables developed in this paper can potentially also be applied to those cases. In the next section, we address the measurement and validity of geography as an instrument for fiscal decentralization. 


\section{The role of geography}

The relationship between geography and decentralization has theoretical and empirical underpinnings. On the theoretical side, Panizza (1999) develops a model of an existing trade-off between the central government's share in the public sector and its total size. He suggests that the equilibrium level of decentralization should be positively correlated with the heterogeneity of tastes for public goods among residents, with the level of democracy, and with country size. A second model by Arzaghi and Henderson (2005) is based on balancing the costs of subnational administration with the "spatial decay" of goods that are provided from the center. Among other factors, they predict higher decentralization the larger is the spatial decay of local public services provided to the hinterland by the central government. Canavire-Bacarreza et al. (2016) build on these two approaches by hypothesizing that geographic heterogeneity and ethnic fractionalization are determinants of "spatial decay" and that their presence will lead to higher levels of fiscal decentralization. Empirically, these authors find significant effects of the Geographic Fragmentation Index (GFI) and country size on fiscal decentralization. Acknowledging the timeinvariance of geography-based variables for estimation approaches involving differencing, Canavire-Bacarreza et al. (2016) interact geography with infrastructure, with the rationale that the effects of geography should diminish over time with the development of infrastructure. With this interaction term, the impact of geography on decentralization decreases, but it still remains important and statistically significant. For example, Panizza (1999) finds a strong positive effect of country size and ethnic fractionalization on fiscal decentralization. These same results are found to be robust using different control variables by Treisman (2006) and Martinez-Vazquez and Timofeev (2009). Jilek (2018) argues that the level of decentralization in government 
expenditure in Europe is increasing in land area and population size, as well as ethnic, language and regional fractionalization.

On the other hand, the effect of geography on economic growth has been the subject of a fierce debate in the literature between the proponents of the "geography hypothesis" (Sachs and Warner, 1997 and others) and the proponents of the "institutions hypotheses" (Acemoglu, Johnson and Robinson, 2001 and others). The proponents of the geography hypothesis argue that geography matters for growth because of many factors, including distance to major ports along rivers or seas/oceans, land-lockedness, the prevalence of environmental diseases in the latter type of countries, or the availability of large natural resource endowments. In contrast, the "institutions hypothesis" proponents argue that the key factor in economic growth is the institutional framework that countries adopt and that geography only plays an indirect role through institutions, so that after accounting for institutions, the effect of geography on economic growth should vanish. ${ }^{5}$

Interestingly, the dimensions of geography of interest to this paper (elevation and country size) that we use as instrumental variables are the least frequent variables used to explain the potential role of geography in the economic growth literature. ${ }^{6}$ The view we take is that even though there is a potential direct effect of geography on economic growth, this relationship is questionable on several grounds. First, geography may affect the diversity or composition of economic activity as opposed to the level of economic activity itself. People living in mountainous areas may not be able to grow certain crops, but they do participate in other

\footnotetext{
${ }^{5}$ See Przeworksi (2004) and Lorenz et al. (2005) for more discussion on the debate.

${ }^{6}$ For example, Nunn and Puga (2009) use terrain ruggedness to explain economic growth problems in Africa, while Sachs et al. (2002) use distance to ports and the average slope of the land to explain economic growth in China's provinces; however, the results in both papers are not statistically significant.
} 
economic activities that are not available to lowlanders. The world offers sufficient examples of countries with no geographic advantages that have emerged as economic powers arguably as a consequence of other factors, such as strong institutions or high-quality human capital, as in the case of Japan, South Korea, Switzerland, etc. Second, geography being exogenous (i.e., economic growth does not affect geography) can affect economic growth through other channels, such as trade, institutions, or infrastructure. However, these channels can be controlled more or less successfully since none of them are fully unobserved. To summarize, if these considerations are valid, using geography as an instrument for fiscal decentralization in explaining growth is a valid strategy.

\section{Data and empirical framework}

We construct a comprehensive panel (time-series cross-country) dataset for over 70 countries for the period of 1981-2010, although the sample varies depending on the specification and variables used due to differing data availability. Most of the variables were extracted from the World Bank's World Development Indicators (WDI), while the fiscal decentralization variables are from IMF's Government Finance Statistics (GFS), complemented by the use of OECD databases. The variable descriptions and sources are listed in the Appendix (Table A1). We average the values for five-year periods to smooth the data over the macroeconomic cycle and also to allow us to focus on the long-run effects. The summary statistics of the main variables are also reported in the Appendix (Table A2).

To measure decentralization, we use two conventional and frequently utilized measures: (1) the ratio of total subnational revenues to general government revenues, and (2) the ratio of total subnational expenditure to general government expenditures. The potential flaws associated with these two measures have been frequently discussed in the literature (missing values, etc.), 
but as noted by Letelier (2005), there is no evidence of a systematic measurement error across countries in the GFS data. Therefore, regression results should not be affected if the sample is large enough, which it is in our case.

The reason for using these two measures of decentralization is that they capture different dimensions of fiscal decentralization and their impact is therefore potentially different. Frequently, asymmetric expenditure decentralization is associated with stronger central administrations and therefore may not always imply effective decentralization (MartinezVazquez and Timofeev, 2010). On the other hand, revenue decentralization is usually harder to achieve politically, but it may report higher accountability and more efficient expenditures. While both measures of decentralization often go hand in hand, using both measures in one equation is likely to lead to multicollinearity issues.

\subsection{Measuring geography}

We measure geography on two dimensions, using the Geographic Fragmentation Index (GFI) previously developed by Canavire-Bacarreza et al. (2016) and country size. ${ }^{7}$ The data for the GFI are acquired from NASA's Earth Observing System Data and Information System (EOSDIS) hosted by The Center for International Earth Science Information Network (CIESIN) at Columbia University. The data are available for years 1990, 1995, 2000 and 2010. Since there is low variation in the GFI over time, to address the missing values for 1981-1985, we assume them to be the same as for 1986-1990, while data for 2001-2005 are assumed to be the same as for 2006-2010.

\footnotetext{
${ }^{7}$ Given that the GFI and country size are actually correlated, instead of using country size per se, we use the residuals of the regression of GFI on country size in its place.
} 
The GFI reflects the weighted probability that two individuals taken at random in the country do not live in similar altitude zones, with the weight matrix calculated as the average distance between altitudes. Thus, the index is simply calculated as:

$$
1-\sum_{j=1}^{J} \sum_{i=1}^{N}\left(w_{i j} \frac{n_{i}}{N}\right)^{2}
$$

where $\frac{n_{i}}{N}$ is the share of the population by elevation and $w_{i j}$ measures the distance between altitude $\mathrm{i}$ and altitude $\mathrm{j}$. This measure goes from zero, which corresponds to a case where all the population is settled in the same altitude zone, to one which corresponds to the implausible case where each lives in a different altitude. In general, geographical fragmentation will increase with the number of altitude-zones and equal weight for each group. ${ }^{8}$ Figure 1 shows the geographical fragmentation index in 1990 ranked from countries that are less fragmented (i.e., Belarus, Paraguay) to countries that show high levels of geographical fragmentation (i.e., Colombia, China, or Switzerland).

\footnotetext{
${ }^{8}$ The methodology applied for the index is similar to the one applied by Lora et. al. (2003) for geographical zones and that applied by Hudson (1972) for population.
} 
Figure 1 Global Map of Geographical Fragmentation Index (Own Calculation for 1990) ${ }^{9}$

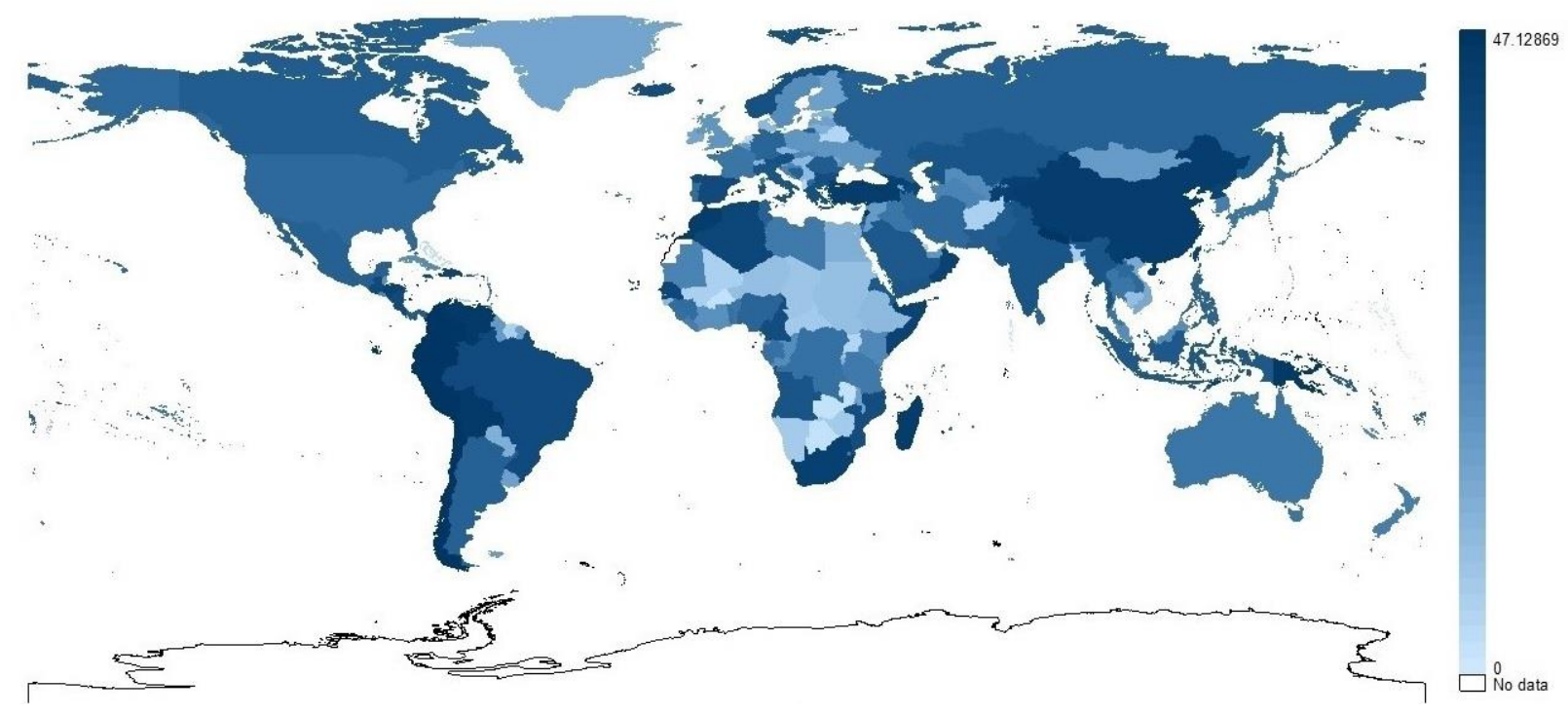

For estimating the impact of fiscal decentralization on economic growth, we follow the conventional neoclassical economic growth specification (Barro, 1990; Mankiw et al., 1992;

Davoodi and Zou, 1998). Specifically, we control for the log of initial GDP per capita to account for convergence and also control for population growth, human capital, ${ }^{10}$ openness to international trade, democratic governance, quality of institutions, ${ }^{11}$ and ethnolinguistic fractionalization. We also add regional and time dummies.

The estimation of the impact of fiscal decentralization on economic growth is done in two stages:

First stage:

$$
\mathrm{FD}_{\mathrm{it}}=\alpha_{0}+\gamma \mathrm{X}_{\mathrm{it}}+\delta \mathrm{Z}_{\mathrm{it}}+\varepsilon_{\mathrm{it}}
$$

\footnotetext{
${ }^{9}$ The Geographic Fragmentation Index in the figure varies from 0 to 100 (probability * 100), with 100 being most fragmented geographic elevation (all individuals living in different altitude), while 0 is for least fragmentation of elevation (all individuals living in the same altitude). Darker color indicates higher fragmentation.

${ }^{10}$ Human capital is proxied by infant mortality. Although less than perfect, this variable allows for the most complete panel dataset for the timespan that we use.

${ }^{11}$ Here, we use the political rights from Freedom House.
} 
Second stage: $\quad \operatorname{GDPpcgr}_{i t}=\rho_{0}+\theta \mathrm{X}_{\mathrm{it}}+\sigma \widehat{\mathrm{FD}}_{1 \mathrm{t}}+\mathrm{u}_{\mathrm{it}}$

where $\mathrm{FD}_{\mathrm{it}}$ is the measure of fiscal decentralization, while $\widehat{\mathrm{FD}}_{\mathrm{it}}$ is the predicted values from the first stage equation; GDPpcgr ${ }_{i t}$ is the growth in GDP per capita, our measure of economic

growth; $\mathrm{X}_{\mathrm{it}}$ is the set of control variables listed above; and $\mathrm{Z}_{\mathrm{it}}$ is the set of country-specific geography instrumental variables, namely, the GFI and country size.

Our primary interest is in the coefficient $\sigma$, which represents the exogenous causal effect of fiscal decentralization on economic growth. This coefficient can be interpreted as the percentage point change in GDP per capita growth associated with a one percentage point change in the share of subnational governments in either the total government revenue or expenditure.

To address the endogeneity of fiscal decentralization, we use the geography IVs that are exogenous to economic growth and other factors and which we claim, based on economic logic and statistical tests, do not directly affect economic growth after controlling for the role of institutions. The low time variance of geography presents a problem when using panel estimation methods like fixed effects or GMM that imply differencing of the data over time. For this reason, we use the conventional pooled OLS with region- and time-specific dummy variables; random effects estimation results are provided as a robustness check.

\section{Results}

\subsection{Simple and IV OLS results}

As reported in the first two columns of Table 1, we find a positive and significant impact of fiscal decentralization on economic growth for both measures of fiscal decentralization for the OLS estimates: a ten-percentage point increase in the share of subnational government 
expenditures is expected to increase GDP per capita growth by 0.2 percentage points; or a tenpercentage point increase in the share of subnational government revenues is expected to increase GDP per capita growth by 0.31 percentage points. Overall, these findings support the side of the literature that previously found a positive impact of fiscal decentralization on economic growth (Yilmaz, 1999; Ebel and Yilmaz, 2002; Thiessen, 2003; Breuss and Eller, 2004; Iimi, 2005). More specifically, our results are relatively close to previous comparable findings of 0.15 for developed countries in expenditure decentralization (Thiessen, 2003), but are considerably lower than the 0.6 percentage points reported by limi (2005) for a sample of both developed and developing countries. For the other control variables, the negative significant coefficient for infant mortality and the positive and significant one for trade openness replicate previous findings in the literature.

Table 1. Estimation of the impact of fiscal decentralization on economic growth

\begin{tabular}{|c|c|c|c|c|}
\hline \multirow[b]{2}{*}{ VARIABLES } & \multicolumn{2}{|c|}{ OLS } & \multicolumn{2}{|c|}{ IV } \\
\hline & $\begin{array}{l}\text { Expenditure } \\
\text { Decentralization }\end{array}$ & $\begin{array}{l}\text { Revenue } \\
\text { Decentralization }\end{array}$ & $\begin{array}{l}\text { Expenditure } \\
\text { Decentralization }\end{array}$ & $\begin{array}{l}\text { Revenue } \\
\text { Decentralization }\end{array}$ \\
\hline Expenditure decentralization & $\begin{array}{l}0.020 * \\
(0.012)\end{array}$ & & $\begin{array}{l}0.042 * * \\
(0.021)\end{array}$ & \\
\hline Revenue decentralization & & $\begin{array}{l}0.031 * * * \\
(0.012)\end{array}$ & & $\begin{array}{l}0.041 * * \\
(0.020)\end{array}$ \\
\hline Log of initial GDP per capita & $\begin{array}{l}-2.045 * * * \\
(0.455)\end{array}$ & $\begin{array}{l}-2.171 * * * \\
(0.403)\end{array}$ & $\begin{array}{l}-2.379 * * * \\
(0.478)\end{array}$ & $\begin{array}{l}-2.293 * * * \\
(0.404)\end{array}$ \\
\hline Population growth (WDI) & $\begin{array}{l}-61.358 * * \\
(23.667)\end{array}$ & $\begin{array}{l}-63.259 * * \\
(25.359)\end{array}$ & $\begin{array}{l}-58.663 * * \\
(24.577)\end{array}$ & $\begin{array}{l}-60.958 * * \\
(24.842)\end{array}$ \\
\hline Infant mortality (WDI) & $\begin{array}{l}-0.030 * * * \\
(0.008)\end{array}$ & $\begin{array}{l}-0.030 * * * \\
(0.008)\end{array}$ & $\begin{array}{l}-0.034 * * * \\
(0.008)\end{array}$ & $\begin{array}{l}-0.031 * * * \\
(0.007)\end{array}$ \\
\hline Trade openness (PWT) & $\begin{array}{l}0.008 * * \\
(0.003)\end{array}$ & $\begin{array}{l}0.009 * * \\
(0.004)\end{array}$ & $\begin{array}{l}0.010 * * * \\
(0.004)\end{array}$ & $\begin{array}{l}0.010 * * \\
(0.004)\end{array}$ \\
\hline Political rights $(\mathrm{FH})$ & $\begin{array}{l}-0.095 \\
(0.101)\end{array}$ & $\begin{array}{l}-0.049 \\
(0.093)\end{array}$ & $\begin{array}{l}-0.072 \\
(0.098)\end{array}$ & $\begin{array}{l}-0.052 \\
(0.088)\end{array}$ \\
\hline Ethno-linguistic fractionalization (AL) & $\begin{array}{l}0.174 \\
(0.632)\end{array}$ & $\begin{array}{l}-0.596 \\
(0.594)\end{array}$ & $\begin{array}{l}0.069 \\
(0.662)\end{array}$ & $\begin{array}{l}-0.753 \\
(0.648)\end{array}$ \\
\hline Constant & $\begin{array}{l}20.681 * * * \\
(4.357)\end{array}$ & $\begin{array}{l}21.994 * * * \\
(3.960)\end{array}$ & $\begin{array}{l}23.181 * * * \\
(4.386)\end{array}$ & $\begin{array}{l}22.924 * * * \\
(3.855)\end{array}$ \\
\hline Regional dummies & YES & YES & YES & YES \\
\hline Time period dummies & YES & YES & YES & YES \\
\hline Observations & 285 & 301 & 285 & 301 \\
\hline R-squared & 0.315 & 0.391 & 0.301 & 0.388 \\
\hline
\end{tabular}


The results from using the IVs approach are reported in the last two columns of Table 1. The full tables including the first-stage regressions are presented in Table A3 in the Appendix. Again, we find a highly significant and positive impact of fiscal decentralization on economic growth for both measures of decentralization, and both coefficients are larger than the OLS estimates. In this case, a ten percentage point increase in the share of subnational government expenditures is expected to increase GDP per capita growth by 0.42 percentage points, while a ten percentage point increase in the share of subnational government revenues is expected to increase GDP per capita growth by 0.41 percentage points. Nevertheless, the estimated size of the impact after correcting for endogeneity is smaller than the average coefficient of 0.6 reported in previous studies that found a positive impact on both developed and developing countries (Iimi, 2005) and is also smaller than the coefficients found within-country, which usually report the estimated coefficients above.

Again, we observe mostly expected results for the other control variables. We find population growth to be highly significant and negative as most of the previous literature reports, while infant mortality is also highly significant and negative as expected. We also find a positive and significant impact of trade openness on economic growth. The rest of the control variables are insignificant.

Regarding the first-stage results (see Table A3 in the Appendix), consistent with Canavire-Bacarreza, et al. (2016), we find that in both expenditure and revenue decentralization cases, the instruments are positive and highly significant, as expected. Moreover, since we use country clustered standard errors, we refer to the Kleibergen-Paap rk Wald F statistic, which is 14 in the case of expenditure decentralization and 15.6 in the case of revenue decentralization. 
Based on Stock and Yogo's rule of thumb, both are higher than the critical F test value at the 5 percent significance level, so we can reject the claim that the instruments are weak in both the expenditure and revenue regressions cases (Stock and Yogo, 2005).

\subsection{Heterogeneous impact of fiscal decentralization.}

Less-developed countries tend to have lower levels of fiscal decentralization than developed countries. Carniti et al. (2018) find a bell-shaped relationship between fiscal decentralization and growth based on a theoretical model that they developed for European countries. When we look at the groups of countries that are members of the OECD, we observe a similar pattern in the last decade, with the average share of subnational government in total government revenue and expenditure being higher compared to that of non-OECD countries (Table 2). In the case of revenue decentralization, the average share of the subnational government in OECD countries is 21.5 percent versus 17.6 percent in non-OECD countries. The difference is even larger in the case of expenditure decentralization, with an average share of subnational government in the expenditure of 29.2 percent for the OECD group versus 17.5 percent for the non-OECD group.

Table 2. Summary statistics of fiscal decentralization measures, 2000-2012

\begin{tabular}{lcccc}
\hline & \multicolumn{2}{c}{ Revenue Decentralization } & \multicolumn{2}{c}{ Expenditure Decentralization } \\
\cline { 2 - 5 } & OECD & Non-OECD & OECD & Non-OECD \\
\hline Mean & $21.50 \%$ & $17.60 \%$ & $29.20 \%$ & $17.50 \%$ \\
Standard Deviation & $14.00 \%$ & $14.90 \%$ & $14.40 \%$ & $14.40 \%$ \\
Minimum & $1.20 \%$ & $0.13 \%$ & $3.90 \%$ & $0.30 \%$ \\
Maximum & $63.50 \%$ & $84.10 \%$ & $65.40 \%$ & $81.80 \%$ \\
\hline
\end{tabular}

Source: Authors' calculations.

Note: Revenue decentralization is measured as the share of sub-national revenue in total revenue; expenditure decentralization is measured as the share of sub-national expenditure in total expenditure.

These differences are relevant because the impact of fiscal decentralization on economic growth may differ from developed to developing countries. In addition to quite different levels of 
decentralization, there may be other differences that may affect that basic relationship, such as governance institutions or the quality and skills of public employees. Since it is practically impossible to control for these features, we divide the sample into two groups of countries: developed versus developing (OECD vs non-OECD). Ideally, we would like to conduct a quintile effect analysis; however, the sample size is too low for each quintile to reach any reliable conclusions.

Table 3 presents the IV OLS estimation of economic growth equation for OECD and non-OECD countries (full tables including first-stage regressions are presented in Tables A4 and A5 of the Appendix). For the OECD sample, we find that the impact of both expenditure and revenue decentralization is still positive and significant. However, the magnitude of the impact changes for both types of fiscal decentralization measures. In the case of expenditure decentralization, we find that a ten-percentage-point increase in the share of subnational government expenditure in total government expenditure is expected to increase the GDP per capita growth by 0.25 percentage points, which is 40 percent lower than the magnitude found in the full sample of countries. In contrast, the impact of revenue decentralization is larger, and we find that a ten-percentage-point increase in the share of subnational government revenue in total government revenue is expected to increase the GDP per capita growth by 0.52 percentage points, which is approximately 27 percent larger in magnitude compared to the full sample. 
Table 3. IV OLS estimation of the impact of fiscal decentralization on economic growth by country samples

\begin{tabular}{lllll} 
& \multicolumn{2}{c}{ OECD } & \multicolumn{2}{c}{ Non-OECD } \\
\cline { 2 - 5 } \multicolumn{1}{c}{ VARIABLES } & $\begin{array}{c}\text { Expenditure } \\
\text { Decentralization }\end{array}$ & $\begin{array}{c}\text { Revenue } \\
\text { Decentralization }\end{array}$ & $\begin{array}{c}\text { Expenditure } \\
\text { Decentralization }\end{array}$ & $\begin{array}{c}\text { Revenue } \\
\text { Decentralization }\end{array}$ \\
\hline Expenditure decentralization & $0.025^{* *}$ & & 0.050 & \\
Revenue decentralization & $(0.010)$ & & $(0.032)$ & 0.047 \\
& & $0.052^{* *}$ & & $(0.032)$ \\
Log of initial GDP per capita & $-2.173^{* * *}$ & $(0.023)$ & & $-1.468^{* *}$ \\
& $(0.384)$ & $-3.435^{* * *}$ & $-1.596^{* *}$ & $(0.600)$ \\
Population growth (WDI) & -2.701 & $(0.559)$ & $(0.636)$ & -41.115 \\
Infant mortality (WDI) & $(28.353)$ & $(25.579)$ & -39.579 & $(34.272)$ \\
& -0.013 & -0.096 & $-0.025^{* * *}$ & $-0.021^{* *}$ \\
Trade openness (PWT) & $(0.117)$ & $(0.087)$ & $(0.010)$ & $(0.009)$ \\
& $0.007^{* *}$ & $0.011^{* * *}$ & 0.013 & 0.010 \\
Political rights (FH) & $(0.003)$ & $(0.004)$ & $(0.009)$ & $(0.010)$ \\
& -0.503 & -0.291 & $-0.222^{*}$ & -0.163 \\
Ethno-linguistic & $(0.355)$ & $(0.273)$ & $(0.134)$ & $(0.112)$ \\
fractionalization (AL) & $-1.283^{* * *}$ & $-2.255^{* *}$ & 0.971 & 0.177 \\
Constant & $(0.472)$ & $(1.060)$ & $(1.347)$ & $(1.410)$ \\
& $22.434^{* * *}$ & $34.928^{* * *}$ & $15.570^{* * * *}$ & $14.786^{* * *}$ \\
Regional dummies & $(4.476)$ & $(5.238)$ & $(5.668)$ & $(5.516)$ \\
Time period dummies & YES & YES & YES & YES \\
Observations & YES & YES & YES & YES \\
R-squared & 138 & 147 & 147 & 154 \\
Note: Country clustered standard errors are in parentheses, stars reflect the significant levels $-* * * p<0.01, * * p<0.05, * p<0.1$ \\
\end{tabular}

As for the non-OECD countries sample, we find that the impact of both expenditure and revenue decentralization is insignificant at the 10 percent confidence level; however, both are positive and significant at a weaker 14 percent confidence level. In terms of impact, a tenpercentage-point increase in the share of subnational government expenditures would be expected to increase the GDP per capita growth by 0.5 percentage points, while a ten-percentagepoint increase in the share of subnational government revenue in total government revenues would be expected to increase the GDP per capita growth by 0.47 percentage points. The impact of expenditure decentralization is larger than in developed countries, while the impact of revenue decentralization is smaller but close. These weaker results for developing countries give some 
support to a different strand of the previous literature that does not find a significant impact of fiscal decentralization on economic growth (Woller and Phillips, 1998).

As for the first stage of IV estimations (reported in Tables A4 and A5 in the Appendix), country size is still highly significant and positive, while the GFI loses significance at the 10 percent confidence level for the OECD sample. However, the joint significance of the instruments still holds. The Kleibergen-Paap rk Wald F statistic is at 11.6 for expenditure decentralization and is acceptable within a 15 percent confidence level, according to the StockYogo classification. However, the F statistic falls to 3.3 in the case of revenue decentralization, although the Cragg-Donald F statistic is above 11.6. For the non-OECD sample, we observe that both the GFI and country size are highly significant and positive, as in the case of the full sample, and the Wald F-statistic is 23 and 35 for expenditure and revenue IV estimations, respectively, which are way above the 10 percent confidence level, thus providing strong evidence for non-weak IVs. We may speculate that the impact of the GFI may be lower for developed countries since they have better infrastructure, which may undermine the impact of geographical features within a country.

What might explain the difference in impact between developing and developed countries? While this question goes beyond the scope of this paper, one hypothesis that has been advanced in previous literature is the potential nonlinear relationship between fiscal decentralization and economic growth (Thiessen, 2003; Carniti et al., 2018). Drawing on this literature, it is expected that more developed countries (OECD) may present higher levels of fiscal decentralization and a stronger impact on economic growth, while low income countries may show weaker effects on economic growth. A potential argument for this lies in the fiscal decentralization design of non-OECD vs OECD countries. Non-OECD countries have weaker 
institutions, a less strict rule of law, and worse economic and social conditions that restrain the effects of fiscal decentralization compared to those of OECD countries. Moreover, fiscal decentralization design may also help explain the differential effects of our decentralization measures. Non-OECD country results are higher for our expenditure measure than for our revenue measure. This may be due to the limited tax autonomy that subnational governments have in low income countries compared to that of the expenditures. In contrast, OECD countries present higher levels of tax autonomy, which in turn translates into higher effects of revenue decentralization on growth compared to that of non-OECD countries and even to their own expenditure decentralization.

\subsection{Robustness checks}

We provide several robustness checks of the main results presented above. First, while we cannot perform fixed-effect estimations, to exploit the panel data at hand, we estimate a random effects model. As can be seen in Table A6 in the Appendix, the results for the random effect estimation show approximately the same coefficients for the impact of fiscal decentralization as the simple OLS regression. The same can be said for the estimated coefficients using IV random effect estimation and IV OLS results (Table A7). Second, to partially address the potential nonlinear nature of the relationship between fiscal decentralization and economic growth raised in the previous section, we introduce a log form version for GDP per capita growth, which is consistent with the potential inverse U-shape hypothesized in the previous literature. We again find that the GFI and land size are non-weak and valid instruments in the first stage and that fiscal decentralization has a significant impact on economic growth for developed countries (Table A8). However, the significance for the whole sample of countries now vanishes. 
Third, we further explore the joint impact of fiscal decentralization variables. Although expenditure and revenue decentralization frequently go hand in hand, they address and measure fundamentally different aspects of fiscal decentralization and capture different mechanisms of the impact of fiscal decentralization on economic growth (Martinez-Vazquez and Timofeev, 2010). The results partially confirm that when we include the other fiscal decentralization measure in the first and second stages, we find that the other fiscal decentralization measure is highly significant in the first stage, while in the second stage, none of the fiscal decentralization measures are significant (Table A9). This result suggests that overall, fiscal decentralization efforts go hand in hand, and when a country decides to decentralize, it decentralizes both expenditure and revenue components of the budget. At the same time, due to a high correlation, the second stage results suffer from multicollinearity and do not yield any meaningful results. In other words, while they are highly correlated, it makes sense to study them separately to identify the separate mechanism through which fiscal decentralization affects economic growth.

Fourth, we test the sensitivity of the results to a different period of averaging in order to account for possible business cycles that are longer than five years; specifically, we perform tenyear averaging of all variables. This obviously decreases the sample size, but it is encouraging to see that the main results still stand. We find again that the GFI and land size are valid and strong instruments in the first stage, and that fiscal decentralization measures have a significant impact on economic growth for all samples of countries (Table A10). In fact, compared to our base main results, the magnitudes of the impact are larger by approximately 15-20 percent. Finally, we look at the validity and strength of the instrument separately. We argue that both the GFI and land size jointly determine fiscal decentralization in the first stage and that they should be used jointly as instruments. When we use these instruments separately, the GFI is not significant in the first 
stage (Table A11), and land area is usually significant in the first stage (Table A12). However, none of the fiscal decentralization measures are significant in the second stage when they are based on either separate instrumental variable. This strongly suggests that as hypothesized, the GFI captures an important dimension through which the causal impact of fiscal decentralization on economic growth is identified.

\section{Conclusion}

The question of the causal impact of fiscal decentralization on economic growth has been one of the most researched issues in the literature on fiscal federalism. However, a general glance at this vast empirical literature reveals that practically all of the previous papers are flawed because they suffer from a fundamental identification problem. This problem arises from the presence of "reverse causality" or "simultaneity," where fiscal decentralization and economic growth simultaneously affect (cause) each other. Any estimation of the causal impact of fiscal decentralization without accounting for these identification issues is flawed and cannot be considered truly reliable.

In this paper, we reason that the Geographic Fragmentation Index (GFI) and country are valid instruments because they are highly correlated with fiscal decentralization and neither is directly or indirectly correlated with economic growth, except through fiscal decentralization. ${ }^{12}$ The basic idea is that geographic conditions, such as significant variations in elevation and country size, have exerted a large influence on the degree of heterogeneity in tastes and preferences for local and regional public goods and services in countries around the world. The

\footnotetext{
${ }^{12}$ Again, even though certain specific dimensions of geography other than elevation heterogeneity can play a direct role in economic growth, we argue that by controlling for the role of institutions, the role of geography can be neutralized or eliminated, as has been shown by Acemoglu, Johnson and Robinson (2001) and Easterly and Levine (2003).
} 
persistence of heterogeneity in demand for public services eventually leads to a heightened demand for fiscal autonomy and fiscal decentralization. Even though the effect of geography can be weakened by migration, the overall effect is likely to endure, due to the assimilation of newcomers.

In the empirical analysis, we find that both geography measures are strong and valid as instruments for fiscal decentralization in the first stage of the 2SLS approach. Moreover, we find that fiscal decentralization measured as a share of expenditure or revenue of subnational government in total general government expenditure or revenue has a significant positive impact on economic growth, especially in the case of developed countries. Overall, these findings support the side of the previous literature that finds a positive impact of fiscal decentralization on economic growth. However, when we separate our observations into two subsamples of developing and developed countries, the strong statistically significant results only hold for the group of developed countries. These results hold some important policy implications, especially because the rationale for decentralization reforms in the developing world has often been based on the beneficial impact that these reforms will have on economic growth. However, the impact is not a negative one, and fiscal decentralization reform can offer many other positive outcomes to developing countries that adopt those policies. 


\section{References}

Acemoglu, D., Johnson, S., \& Robinson, J. A. (2000). "The colonial origins of comparative development: An empirical investigation" (No. w7771). National bureau of economic research.

Akai, Nobuo and Sakata, Masayo. (2002). "Fiscal Decentralization Contributes to Economic Growth: Evidence from State-Level Cross-Section Data for the Unites States", Journal of Urban Economics, 52(1): 93-108.

Arzaghi, M. and J. V. Henderson (2005). "Why countries are fiscally decentralizing." Journal of Public Economics 89(7): 1157-1189.

Barro, R. J. (1990). “Government spending in a simple model of endogenous growth.” Journal of Political Economy 98: 103-25.

Baskaran, T. and Feld, L.P. (2013) "Fiscal decentralization and economic growth in OECD countries: Is there a relationship?” Public Finance Review (doi: 10.1177/1091142112463726)

Baskaran, T., Feld, L. P., \& Schnellenbach, J. (2016). Fiscal Federalism, Decentralization, and Economic Growth: A Meta-Analysis. Economic Inquiry, 54(3), 1445-1463.

Blöchliger, H. and O. Akgun (2018), "Fiscal decentralisation and economic growth", in Kim, J. and S. Dougherty (eds.), Fiscal Decentralisation and Inclusive Growth, OECD Publishing, Paris, https://doi.org/10.1787/9789264302488-4-en

Bodman, P., Campbell, H., Heaton, K. A., \& Hodge, A. (2009). "Fiscal decentralisation, macroeconomic conditions and economic growth in Australia" University of Queensland, Macroeconomic Research Group Working Paper.

Brennan, G. and Buchanan J.M. (1980) "The Power to Tax: Analytical Foundations of a Fiscal Constitution." Cambridge, UK: Cambridge University Press

Brueckner, J. (2006) "Fiscal federalism and economic growth." Journal of Public Economics 90(10-11): 2107-2120.

Canavire-Bacarreza, G., Martinez-Vazquez, J., \& Yedgenov, B. (2016). Reexamining the determinants of fiscal decentralization: what is the role of geography?. Journal of Economic Geography, 17(6), 1209-1249.

Carniti, E., Cerniglia, F., Longaretti, R., \& Michelangeli, A. (2018). Decentralization and economic growth in Europe: for whom the bell tolls. Regional Studies, 1-15.

Couderc, N. and Ventelou, B. (2005) "AIDS, economic growth and the epidemic trap in Africa." Oxford Development Studies 33 (3): 417-426.

Davoodi, H., \& Zou, H. F. (1998). "Fiscal decentralization and economic growth: A cross-country study." Journal of Urban economics, 43(2), 244-257.

Dell, M., Jones, B. F., \& Olken, B. A. (2012). "Temperature shocks and economic growth: Evidence from the last half century." American Economic Journal: Macroeconomics, 4(3), 66-95.

Ding, Y., McQuoid, A., \& Karayalcin, C. (2019). Fiscal decentralization, fiscal reform, and economic growth in china. China Economic Review, 53, 152-167. 
Drucker, P. F. (1993), "Post-Capitalist Society”, Routledge.

Easterly, W. and Levine, R. (2003). "Tropics, germs, and crops: how endowments influence economic development." Journal of monetary economics, 50(1), 3-39.

Enikolopov, R. and Zhuravskaya, E. (2007). "Decentralization and political institutions”. Journal of Public Economics 91, 2261-2290.

Ezcurra, R. and Rodríguez-Pose, A. (2011) "Is fiscal decentralization harmful for economic growth? Evidence from the OECD countries.” Journal of Economic Geography 11(4): 619-643.

Feld, L. P. and Schnellenbach, J. (2011) "Fiscal federalism and long-run macroeconomic performance: A survey of recent research. "Environment and Planning C: Government and Policy 29(2): 224-243.

Feld, L.P. Kirchgassner, G. and Schaltegger, C.A. (2004) "Fiscal federalism and economic performance: Evidence from Swiss cantons." Marburg Working Papers in Economics 200420. PhilippsUniversität Marburg.

Feyrer, J. (2009). "Distance, trade, and income-The 1967 to 1975 closing of the Suez Canal as a natural experiment" (No. w15557). National Bureau of Economic Research.

Gallup, J. L., Sachs, J. D., \& Mellinger, A. D. (1999). "Geography and economic development." International regional science review, 22(2), 179-232.

Garman, C., Haggard, S. and Willis E. (2001). "Fiscal decentralization: A political theory with Latin American cases." World Politics, 53(2): 205-236.

Gemmell, N. Kneller, R. and Sanz, I. (2013) "Fiscal decentralization and economic growth in OECD countries: Matching spending with revenue decentralization." Economic Enquiry (DOI: $10.1111 /$ j.1465-7295.2012.00508.x).

Hayek, F.A. (1945) “The use of knowledge in society.” American Economic Review 45: 519-30.

Hooghe L, Marks, G. and Schakel, A. H. (2010) “The Rise of Regional Authority: A Comparative Study of 43 Democracies." London: Routledge.

Hudson, R. L. (1972). “The Hudson-Dunn clustering index revisited”. 475.

Iimi, A. (2005). "Decentralization and economic growth revisited: an empirical note." Journal of Urban Economics, 57(3), 449-461.

Jilek, Milan. (2018). Determinants of Fiscal Decentralization-the Recent Evidence in European Countries.

Kee, W. S. (1977). "Fiscal decentralization and economic development." Public Finance Review 5(1): 79.

Krugman, P. R. and A. Venables (1995). "The seamless world: a spatial model of international specialization.” National Bureau of Economic Research Cambridge, Mass., USA.

La Porta, R., Lopez-de-Silanes, F., Shleifer, A. and Vishny, R. (1999). “The quality of government”. Journal of Law, Economics, and Organization 15 (1): 222-279.

Letelier, L. (2005). "Explaining fiscal decentralization." Public Finance Review 33(2): 155.

Ligthart, J. E., \& Oudheusden, P. (2017). The Fiscal Decentralisation and Economic Growth Nexus Revisited. Fiscal Studies, 38(1), 141-171. 
Lin, J. and Liu, Z. (2000) “Fiscal decentralization and economic growth in China."Economic Development and Cultural Change 49(1): 1-21.

Lora, E., J. L. Gallup, Gaviria A. (2003) "Is geography destiny? lessons from Latin America”, Stanford Social Sciences.

Lorenz, A., Hemmer, H. R., \& Ahlfeld, S. (2005). "The Economic Growth Debate-Geography versus Institutions: Is There Anything Really New?”(No. 34). Entwicklungsökonomische Diskussionsbeiträge/Universität Giessen, Professur für Volkswirtschaftslehre und Entwicklungsländerforschung.

Mankiw G., Romer D., Weil D. (1992). "A contribution to the empirics of economic growth.” Quarterly Journal of Economics, 107 (1992), pp. 407-437

Martinez-Vazquez, J. and R. McNab (2003). "Fiscal decentralization and economic growth." World Development 31(9): 1597-1616.

Martinez-Vazquez, J. and A. Timofeev (2009). "A fiscal perspective of state rescaling." Cambridge Journal of Regions, Economy and Society 2(1): 85.

Martinez-Vazquez, J., Lago-Penas, S., and Sacchi A. (2016) "The Impact of Fiscal Decentralization: A Survey”, Journal of Economic Surveys, Vol. 00, No. 00, pp. 1-35.

Masters, W. A., \& McMillan, M. S. (2001). "Climate and scale in economic growth.” Journal of Economic Growth, 6(3), 167-186.

McArthur, J. W., \& Sachs, J. D. (2001). "Institutions and geography: comment on Acemoglu, Johnson and Robinson (2000)" (No. w8114). National bureau of economic research.

McCord, G. C., \& Sachs, J. D. (2013). "Development, Structure, and Transformation: Some Evidence on Comparative Economic Growth" (No. w19512). National Bureau of Economic Research.

Nunn, N. and D. Puga (2009). "Ruggedness: The Blessing of Bad Geography in Africa." NBER Working Papers 14918. Cambridge, MA, National Bureau of Economic Research.

Oates, W. (1972) “Fiscal Federalism.” New York: Harcourt Brace Jovanovich.

Oates, Wallace (1995), "Comment on Conflicts and Dilemmas of Decentralization by Rudolf Hommes", in M. Bruno and B. Pleskovic (eds.), Annual World Bank Conference on Development Economic, The World Bank, Washington, pp. 351-353.

Panizza, U. (1999). "On the determinants of fiscal centralization: Theory and evidence." Journal of Public Economics 74(1): 97-139.

Perez-Sebastian, F. and Raveh, O. (2013). "The natural resource curse, fiscal decentralization, and agglomeration economies". OxCarre Working Papers 112, Oxford Centre for the Analysis of Resource Rich Economies, University of Oxford.

Plümper T. and Troeger V.E. (2007), "Efficient Estimation of Time-Invariant and Rarely Changing Variables in Finite Sample Panel Analyses with Unit Fixed Effects", Political Analysis (2007) 15 (2): 124-139.

Przeworski, A. (2004). “Institutions Matter?” 1. Government and opposition, 39(4), 527-540. 
Qian, Y. and Weingast, B. (1997) "Federalism as a commitment to preserving market incentives.” Journal of Economic Perspectives 11 (4): 83-92.

Qiao, Y., Martínez-Vázquez, J. and Xu, J. (2008) "The trade-off between growth and equity in decentralization policy: China's experience.” Journal of Development Economics 86 (1): 112-128.

Rodrik, D., Subramanian, A., \& Trebbi, F. (2004). "Institutions rule: the primacy of institutions over geography and integration in economic development." Journal of economic growth, 9(2), 131-165. Sachs, J. D. (2003). "Institutions don't rule: direct effects of geography on per capita income” (No. w9490). National Bureau of Economic Research.

Sachs, J. D., \& Warner, A. M. (1997). "Sources of slow growth in African economies.” Journal of African economies, 6(3), 335-376.

Thiessen, U. (2003) "Fiscal decentralization and economic growth in high-income OECD countries." Fiscal Studies 24(3): 237-274.

Tiebout, C. M. (1956). "A pure theory of local expenditures." The journal of political economy: 416-424.

Treisman, D. (2000). "Decentralization and inflation: Commitment, collective action, or continuity." American Political Science Review 94(4): 837-857.

Treisman, D. (2006) "Fiscal decentralization, governance, and economic performance: A reconsideration." Economics \& Politics 18 (2):219-235.

Wang, F. (2018). The Influences of Fiscal Decentralization on Economic Performance: Empirical Evidence from OECD Countries. Prague Economic Papers, 2018(5), 606-618.

Wilson, J. D. (1986) “A theory of interregional tax competition." Journal of Urban Economics. 19 (3): 296315.

Woller, G. M., \& Phillips, K. (1998). "Fiscal decentralization and IDC economic growth: An empirical investigation." The journal of development studies, 34(4), 139-148.

Wooldridge, J. (2012). Introductory econometrics: A modern approach. Cengage Learning.

World Bank (1996), "World Development Report 1996: From Plan to Market", New York: Oxford University Press. (C) World Bank. https://openknowledge.worldbank.org/handle/10986/5979 License: CC BY 3.0 IGO.

Xie, D. et al. (1999) "Fiscal decentralization and economic growth in the United States." Journal of Urban Economics 45 (2): 228-239.

Yilmaz, S. (1999, January). "The impact of fiscal decentralization on macroeconomic performance." In Proceedings. Annual Conference on Taxation and Minutes of the Annual Meeting of the National Tax Association (pp. 251-260). National Tax Association.

Zhang, T. and Zou, H. (1998) "Fiscal decentralization, public spending, and economic growth in China." Journal of Public Economics 67 (2): 221-240.

Zhang, T., \& Zou, H. F. (2001). "The growth impact of intersectoral and intergovernmental allocation of public expenditure: With applications to China and India." China Economic Review, 12(1), 58-81. 
Zodrow, G. R., and Mieszkowski, P. (1986) "Pigou, Tiebout, property taxation, and the underprovision of local public goods." Journal of Urban Economics 19 (3):356-370. 


\section{Appendix}

Table A1. Description and sources of variables used in regressions

\begin{tabular}{lll}
\hline \multicolumn{1}{c}{ Variable } & \multicolumn{1}{c}{ Description } & \multicolumn{1}{c}{ Source } \\
\hline $\begin{array}{l}\text { Expenditure } \\
\text { decentralization }\end{array}$ & $\begin{array}{l}\text { Share of subnational expenditure in total government } \\
\text { expenditure }\end{array}$ & IMF GFS \\
\hline $\begin{array}{l}\text { Revenue } \\
\text { decentralization }\end{array}$ & $\begin{array}{l}\text { Share of subnational revenue in total government } \\
\text { revenue }\end{array}$ & IMF GFS \\
\hline GFI & Geographic Fragmentation Index & $\begin{array}{l}\text { Canavire-Bacarreza, } \\
\text { Martinez-Vazquez and } \\
\text { Yedgenov (2016) }\end{array}$ \\
\hline Country size & Country area size (residual after regressing on GFI) & $\begin{array}{l}\text { Canavire-Bacarreza, } \\
\text { Martinez-Vazquez and } \\
\text { Yedgenov (2016) }\end{array}$ \\
\hline $\begin{array}{l}\text { GDP per capita } \\
\text { growth }\end{array}$ & $\begin{array}{l}\text { Annual percentage growth rate of GDP at market prices } \\
\text { based on constant local currency }\end{array}$ & WDI \\
\hline Political Rights & $\begin{array}{l}\text { Index of political rights freedom, graded between 1 } \\
\text { (most free) and 7 (least free) }\end{array}$ & Freedom House \\
\hline $\begin{array}{l}\text { Ethnic } \\
\text { fractionalization }\end{array}$ & $\begin{array}{l}\text { Index of ethnic fractionalization, a higher value indicates } \\
\text { higher fractionalization and more diversity of ethnicities. }\end{array}$ & Alesina et al. (2003) \\
\hline GDP per capita & $\begin{array}{l}\text { GDP per capita based on purchasing power parity (PPP) } \\
\text { in constant international dollars. }\end{array}$ & WDI \\
\hline Infant mortality & $\begin{array}{l}\text { A number of infants dying before reaching one year of } \\
\text { age, per 1,000 live births in a given year. }\end{array}$ & WDI \\
\hline Openness & $\begin{array}{l}\text { Exports plus Imports divided by real GDP per capita in } \\
\text { current prices. }\end{array}$ & Penn World Tables \\
\hline
\end{tabular}


Table A2. Summary statistics

\begin{tabular}{|c|c|c|c|c|c|}
\hline & Obs. & Mean & Std. Dev. & Min. & Max. \\
\hline GDP per capita growth (WDI) & 285 & 1.9 & 2.3 & -5.3 & 11.0 \\
\hline$O E C D$ & 138 & 1.9 & 1.6 & -2.1 & 8.3 \\
\hline Non-OECD & 147 & 1.9 & 2.8 & -5.3 & 11.0 \\
\hline Expenditure Decentralization & 285 & 24.0 & 16.4 & 0.6 & 65.4 \\
\hline$O E C D$ & 138 & 30.9 & 15.2 & 4.0 & 65.4 \\
\hline Non-OECD & 147 & 17.5 & 14.8 & 0.6 & 54.9 \\
\hline Revenue Decentralization & 280 & 19.4 & 14.8 & 0.8 & 57.4 \\
\hline$O E C D$ & 138 & 21.6 & 14.6 & 1.2 & 57.4 \\
\hline Non-OECD & 142 & 17.3 & 14.8 & 0.8 & 54.5 \\
\hline $\begin{array}{l}\text { Geographic Fragmentation Index } \\
\text { (GFI) }\end{array}$ & 285 & 35.5 & 7.1 & 3.7 & 47.5 \\
\hline$O E C D$ & 138 & 33.4 & 6.5 & 15.3 & 45.4 \\
\hline Non-OECD & 147 & 37.4 & 7.2 & 3.7 & 47.5 \\
\hline Country size & 285 & $1,313,267$ & $2,466,812$ & 1,993 & $9,458,669$ \\
\hline$O E C D$ & 138 & $1,344,788$ & $2,906,174$ & 21,339 & $9,458,669$ \\
\hline Non-OECD & 147 & $1,283,676$ & $1,977,335$ & 1,993 & $9,197,975$ \\
\hline Population growth (WDI) & 285 & $1.23 \%$ & $0.97 \%$ & $-1.07 \%$ & $4.06 \%$ \\
\hline$O E C D$ & 138 & $0.67 \%$ & $0.61 \%$ & $-0.52 \%$ & $3.55 \%$ \\
\hline Non-OECD & 147 & $1.77 \%$ & $0.95 \%$ & $-1.07 \%$ & $4.06 \%$ \\
\hline Infant mortality (WDI) & 285 & 33.9 & 40.5 & 3.2 & 213.3 \\
\hline$O E C D$ & 138 & 8.5 & 4.1 & 3.2 & 26.5 \\
\hline Non-OECD & 147 & 57.8 & 44.5 & 9.3 & 213.3 \\
\hline Trade openness (PWT) & 285 & 69.8 & 37.1 & 13.1 & 203.9 \\
\hline$O E C D$ & 138 & 70.9 & 31.6 & 18.2 & 161.2 \\
\hline Non-OECD & 147 & 68.7 & 41.7 & 13.1 & 203.9 \\
\hline Political Rights (FH) & 285 & 2.3 & 1.7 & 1 & 7 \\
\hline$O E C D$ & 138 & 1.2 & 0.7 & 1.0 & 6.0 \\
\hline Non-OECD & 147 & 3.3 & 1.7 & 1.0 & 7.0 \\
\hline $\begin{array}{l}\text { Ethno-linguistic Fractionalization } \\
\text { (AL) }\end{array}$ & 285 & $36.4 \%$ & $24.7 \%$ & $0.2 \%$ & $93.0 \%$ \\
\hline$O E C D$ & 138 & $21.9 \%$ & $19.2 \%$ & $0.2 \%$ & $71.2 \%$ \\
\hline Non-OECD & 147 & $50.0 \%$ & $21.3 \%$ & $3.9 \%$ & $93.0 \%$ \\
\hline
\end{tabular}


Table A3. IV OLS estimation of the impact of fiscal decentralization on economic growth

\begin{tabular}{|c|c|c|c|c|}
\hline \multirow{3}{*}{ VARIABLES } & \multirow{2}{*}{\multicolumn{2}{|c|}{$\begin{array}{cc}(1) & (2) \\
\text { Expenditure Decentralization }\end{array}$}} & \multirow{2}{*}{\multicolumn{2}{|c|}{$\begin{array}{c}(3) \\
\text { Revenue Decentralization }\end{array}$}} \\
\hline & & & & \\
\hline & First Stage & Second Stage & First Stage & Second Stage \\
\hline Expenditure decentralization & & $\begin{array}{l}0.042 * * \\
(0.021)\end{array}$ & & \\
\hline Revenue decentralization & & & & $\begin{array}{l}0.041 * * \\
(0.020)\end{array}$ \\
\hline $\begin{array}{l}\text { Geographic fragmentation } \\
\text { index (GFI) }\end{array}$ & $\begin{array}{l}1.244 * * * \\
(0.459)\end{array}$ & & $\begin{array}{l}1.257 * * \\
(0.570)\end{array}$ & \\
\hline Log country size & $\begin{array}{l}4.535 * * * \\
(1.017)\end{array}$ & & $\begin{array}{l}4.582 * * * \\
(1.181)\end{array}$ & \\
\hline Log of initial GDP per capita & $\begin{array}{l}11.600 * * * \\
(3.130)\end{array}$ & $\begin{array}{l}-2.379 * * * \\
(0.478)\end{array}$ & $\begin{array}{l}8.221 * * \\
(3.268)\end{array}$ & $\begin{array}{l}-2.293 * * * \\
(0.404)\end{array}$ \\
\hline Population growth (WDI) & $\begin{array}{l}-282.506 \\
(182.779)\end{array}$ & $\begin{array}{l}-58.663 * * \\
(24.577)\end{array}$ & $\begin{array}{l}-330.104 * * \\
(164.692)\end{array}$ & $\begin{array}{l}-60.958 * * \\
(24.842)\end{array}$ \\
\hline Infant mortality (WDI) & $\begin{array}{l}0.119 * * \\
(0.054)\end{array}$ & $\begin{array}{l}-0.034 * * * \\
(0.008)\end{array}$ & $\begin{array}{l}0.027 \\
(0.061)\end{array}$ & $\begin{array}{l}-0.031 * * * \\
(0.007)\end{array}$ \\
\hline Trade openness (PWT) & $\begin{array}{l}-0.010 \\
(0.046)\end{array}$ & $\begin{array}{l}0.010 * * * \\
(0.004)\end{array}$ & $\begin{array}{l}-0.045 \\
(0.053)\end{array}$ & $\begin{array}{l}0.010^{* *} \\
(0.004)\end{array}$ \\
\hline Political rights $(\mathrm{FH})$ & $\begin{array}{l}-1.457 \\
(0.924)\end{array}$ & $\begin{array}{l}-0.072 \\
(0.098)\end{array}$ & $\begin{array}{l}-0.560 \\
(1.084)\end{array}$ & $\begin{array}{l}-0.052 \\
(0.088)\end{array}$ \\
\hline $\begin{array}{l}\text { Ethno-linguistic } \\
\text { fractionalization (AL) }\end{array}$ & $\begin{array}{l}1.903 \\
(8.326)\end{array}$ & $\begin{array}{l}0.069 \\
(0.662)\end{array}$ & $\begin{array}{l}10.564 \\
(11.130)\end{array}$ & $\begin{array}{l}-0.753 \\
(0.648)\end{array}$ \\
\hline Constant & $\begin{array}{l}-123.066 * * * \\
(30.199)\end{array}$ & $\begin{array}{l}23.181 * * * \\
(4.386)\end{array}$ & $\begin{array}{l}-97.009 * * * \\
(28.053)\end{array}$ & $\begin{array}{l}22.924 * * * \\
(3.855)\end{array}$ \\
\hline Regional dummies & YES & YES & YES & YES \\
\hline Time period dummies & YES & YES & YES & YES \\
\hline Observations & 285 & 285 & 301 & 301 \\
\hline R-squared & & 0.301 & & 0.388 \\
\hline
\end{tabular}


Table A4. IV OLS estimation of the impact of fiscal decentralization on economic growth - OECD sample

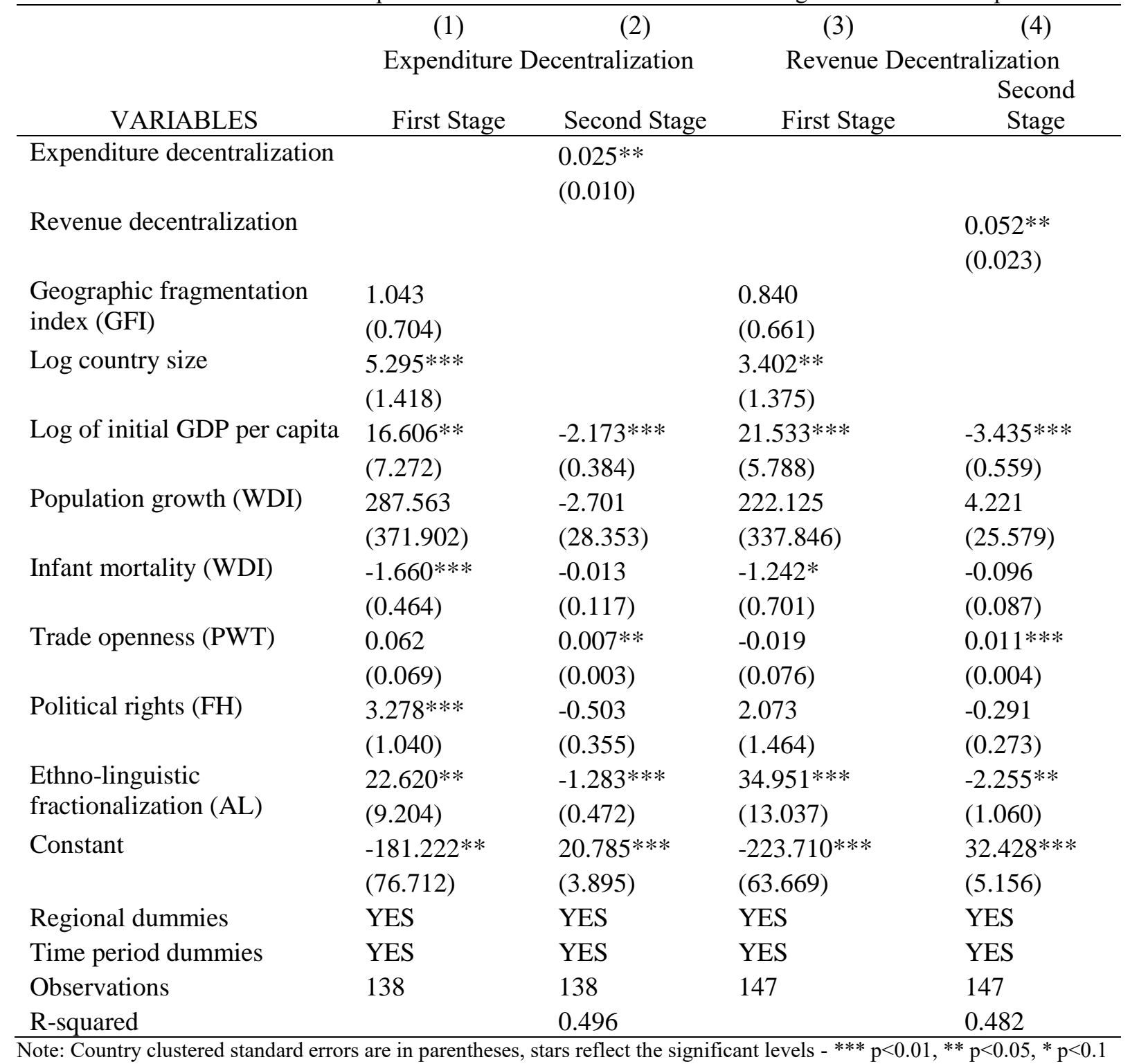


Table A5. IV OLS estimation of the impact of fiscal decentralization on economic growth - Non-OECD sample

\begin{tabular}{|c|c|c|c|c|}
\hline \multirow[b]{3}{*}{ VARIABLES } & \multirow{2}{*}{\multicolumn{2}{|c|}{$\begin{array}{c}(1) \\
\text { Expendi }\end{array}$}} & \multirow{2}{*}{\multicolumn{2}{|c|}{$\begin{array}{c}\text { (3) } \\
\text { Revenue Decentralization }\end{array}$}} \\
\hline & & & & \\
\hline & First Stage & Second Stage & First Stage & Second Stage \\
\hline Expenditure decentralization & & $\begin{array}{l}0.050 \\
(0.032)\end{array}$ & & \\
\hline Revenue decentralization & & & & $\begin{array}{l}0.047 \\
(0.032)\end{array}$ \\
\hline $\begin{array}{l}\text { Geographic fragmentation index } \\
\text { (GFI) }\end{array}$ & $\begin{array}{l}2.525^{* * *} \\
(0.318)\end{array}$ & & $\begin{array}{l}2.279 * * * \\
(0.406)\end{array}$ & \\
\hline Log country size & $\begin{array}{l}5.951^{* * *} \\
(0.723)\end{array}$ & & $\begin{array}{l}5.768^{* * *} \\
(0.844)\end{array}$ & \\
\hline Log of initial GDP per capita & $\begin{array}{l}2.897 \\
(2.962)\end{array}$ & $\begin{array}{l}-1.596 * * \\
(0.636)\end{array}$ & $\begin{array}{l}3.089 \\
(2.879)\end{array}$ & $\begin{array}{l}-1.468 * * \\
(0.600)\end{array}$ \\
\hline Population growth (WDI) & $\begin{array}{l}-517.102 * * * \\
(189.225)\end{array}$ & $\begin{array}{l}-39.579 \\
(31.846)\end{array}$ & $\begin{array}{l}-392.527 * * \\
(192.488)\end{array}$ & $\begin{array}{l}-41.115 \\
(34.272)\end{array}$ \\
\hline Infant mortality (WDI) & $\begin{array}{l}0.099 * * \\
(0.043)\end{array}$ & $\begin{array}{l}-0.025^{* * * *} \\
(0.010)\end{array}$ & $\begin{array}{l}0.056 \\
(0.048)\end{array}$ & $\begin{array}{l}-0.021 * * \\
(0.009)\end{array}$ \\
\hline Trade openness (PWT) & $\begin{array}{l}0.007 \\
(0.035)\end{array}$ & $\begin{array}{l}0.013 \\
(0.009)\end{array}$ & $\begin{array}{l}-0.021 \\
(0.041)\end{array}$ & $\begin{array}{l}0.010 \\
(0.010)\end{array}$ \\
\hline Political rights $(\mathrm{FH})$ & $\begin{array}{l}-1.298^{* *} \\
(0.639)\end{array}$ & $\begin{array}{l}-0.222^{*} \\
(0.134)\end{array}$ & $\begin{array}{l}-0.496 \\
(0.837)\end{array}$ & $\begin{array}{l}-0.163 \\
(0.112)\end{array}$ \\
\hline $\begin{array}{l}\text { Ethno-linguistic } \\
\text { fractionalization (AL) }\end{array}$ & $\begin{array}{l}-16.911^{* *} \\
(7.601)\end{array}$ & $\begin{array}{l}0.971 \\
(1.347)\end{array}$ & $\begin{array}{l}-15.368^{*} \\
(8.807)\end{array}$ & $\begin{array}{l}0.177 \\
(1.410)\end{array}$ \\
\hline Constant & $\begin{array}{l}-96.172^{* * *} \\
(24.283)\end{array}$ & $\begin{array}{l}17.487^{* * *} \\
(4.941)\end{array}$ & $\begin{array}{l}-88.775^{* * *} \\
(21.905)\end{array}$ & $\begin{array}{l}16.862^{* * *} \\
(4.689)\end{array}$ \\
\hline Regional dummies & YES & YES & YES & YES \\
\hline Time period dummies & YES & YES & YES & YES \\
\hline Observations & 147 & 147 & 154 & 154 \\
\hline R-squared & & 0.411 & & 0.494 \\
\hline
\end{tabular}


Table A6. Simple random effect estimation of the impact of fiscal decentralization on economic growth

\begin{tabular}{|c|c|c|}
\hline VARIABLES & $\begin{array}{c}(1) \\
\text { Expenditure } \\
\text { Decentralization }\end{array}$ & $\begin{array}{c}(2) \\
\text { Revenue } \\
\text { Decentralization }\end{array}$ \\
\hline Expenditure Decentralization & $\begin{array}{l}0.023 * \\
(0.013)\end{array}$ & \\
\hline Revenue Decentralization & & $\begin{array}{l}0.032 * * * \\
(0.012)\end{array}$ \\
\hline Log of Initial GDP per capita & $\begin{array}{l}-2.226^{* * * *} \\
(0.472)\end{array}$ & $\begin{array}{l}-2.241 * * * \\
(0.405)\end{array}$ \\
\hline Population growth (WDI) & $\begin{array}{l}-61.149^{* *} \\
(24.387)\end{array}$ & $\begin{array}{l}-60.616^{* *} \\
(25.102)\end{array}$ \\
\hline Infant mortality (WDI) & $\begin{array}{l}-0.034 * * * \\
(0.008)\end{array}$ & $\begin{array}{l}-0.032 * * * \\
(0.008)\end{array}$ \\
\hline Trade openness (PWT) & $\begin{array}{l}0.008 * * \\
(0.004)\end{array}$ & $\begin{array}{l}0.009 * * \\
(0.004)\end{array}$ \\
\hline Political Rights (FH) & $\begin{array}{l}-0.121 \\
(0.105)\end{array}$ & $\begin{array}{l}-0.079 \\
(0.093)\end{array}$ \\
\hline Ethno-linguistic Fractionalization (AL) & $\begin{array}{l}0.504 \\
(0.673)\end{array}$ & $\begin{array}{l}-0.373 \\
(0.632)\end{array}$ \\
\hline Constant & $\begin{array}{l}22.372 * * * \\
(4.498)\end{array}$ & $\begin{array}{l}22.661 * * * \\
(3.967)\end{array}$ \\
\hline Regional dummies & YES & YES \\
\hline Time period dummies & YES & YES \\
\hline Observations & 285 & 301 \\
\hline Number of countries & 68 & 68 \\
\hline
\end{tabular}


Table A7. IV Random effect estimation of the impact of fiscal decentralization on economic growth

\begin{tabular}{|c|c|c|c|c|}
\hline \multirow[b]{4}{*}{ VARIABLES } & \multirow{2}{*}{\multicolumn{2}{|c|}{$\begin{array}{cc}(1) & (2) \\
\text { Expenditure Decentralization }\end{array}$}} & \multirow{2}{*}{\multicolumn{2}{|c|}{$\begin{array}{cc}(3) & (4) \\
\text { Revenue Decentralization }\end{array}$}} \\
\hline & & & & \\
\hline & & Second & & Second \\
\hline & First Stage & Stage & First Stage & Stage \\
\hline Expenditure decentralization & & $\begin{array}{l}0.042^{*} \\
(0.022)\end{array}$ & & \\
\hline Revenue decentralization & & & & $\begin{array}{l}0.041 * * \\
(0.021)\end{array}$ \\
\hline $\begin{array}{l}\text { Geographic fragmentation index } \\
\text { (GFI) }\end{array}$ & $\begin{array}{l}1.244 * * * \\
(0.458)\end{array}$ & & $\begin{array}{l}1.257 * * \\
(0.569)\end{array}$ & \\
\hline Log country size & $\begin{array}{l}4.535 * * * \\
(1.017)\end{array}$ & & $\begin{array}{l}4.582 * * * \\
(1.180)\end{array}$ & \\
\hline Log of initial GDP per capita & $\begin{array}{l}11.600^{* * *} \\
(3.130)\end{array}$ & $\begin{array}{l}-2.379 * * * \\
(0.497)\end{array}$ & $\begin{array}{l}8.221^{* *} \\
(3.267)\end{array}$ & $\begin{array}{l}-2.293 * * * \\
(0.420)\end{array}$ \\
\hline Population growth (WDI) & $\begin{array}{l}-282.506 \\
(182.779)\end{array}$ & $\begin{array}{l}-58.663 * * \\
(25.583)\end{array}$ & $\begin{array}{l}-330.104 \\
(164.69)\end{array}$ & $\begin{array}{l}-60.958^{* *} \\
(25.813)\end{array}$ \\
\hline Infant mortality (WDI) & $\begin{array}{l}0.119 * * \\
(0.054)\end{array}$ & $\begin{array}{l}-0.034 * * * \\
(0.009)\end{array}$ & $\begin{array}{l}0.027 * * \\
(0.060)\end{array}$ & $\begin{array}{l}-0.031^{* * *} \\
(0.008)\end{array}$ \\
\hline Trade openness (PWT) & $\begin{array}{l}-0.010 \\
(0.045)\end{array}$ & $\begin{array}{l}0.010^{* *} \\
(0.004)\end{array}$ & $\begin{array}{l}-0.045 \\
(0.053)\end{array}$ & $\begin{array}{l}0.010^{* *} \\
(0.005)\end{array}$ \\
\hline Political rights $(\mathrm{FH})$ & $\begin{array}{l}-1.457 \\
(0.924)\end{array}$ & $\begin{array}{l}-0.072 \\
(0.102)\end{array}$ & $\begin{array}{l}-0.560 \\
(1.083)\end{array}$ & $\begin{array}{l}-0.052 \\
(0.091)\end{array}$ \\
\hline $\begin{array}{l}\text { Ethno-linguistic fractionalization } \\
\text { (AL) }\end{array}$ & $\begin{array}{l}1.903 \\
(8.326)\end{array}$ & $\begin{array}{l}0.069 \\
(0.690)\end{array}$ & $\begin{array}{l}10.564 \\
(11.13)\end{array}$ & $\begin{array}{l}-0.753 \\
(0.673)\end{array}$ \\
\hline Constant & $\begin{array}{l}-128.9^{* * *} \\
(31.04)\end{array}$ & $\begin{array}{l}23.18^{* * *} \\
(4.566)\end{array}$ & $\begin{array}{l}-105.154 * * * \\
(28.66)\end{array}$ & $\begin{array}{l}22.924 * * * \\
(4.006)\end{array}$ \\
\hline Regional dummies & YES & YES & YES & YES \\
\hline Time period dummies & YES & YES & YES & YES \\
\hline Observations & 285 & 285 & 301 & 301 \\
\hline Number of countries & & 68 & & 68 \\
\hline
\end{tabular}


Table A8. IV OLS estimation of the impact of fiscal decentralization on economic growth by country groups

(dep. var. - log GDP per capita growth)

\begin{tabular}{|c|c|c|c|c|c|c|c|c|c|c|c|c|}
\hline \multirow[b]{4}{*}{ VARIABLES } & $(1)$ & $(2)$ & (3) & $(4)$ & (5) & (6) & $(7)$ & $(8)$ & (9) & $(10)$ & $(11)$ & $(12)$ \\
\hline & \multicolumn{4}{|c|}{ ALL countries } & \multicolumn{4}{|c|}{ OECD countries } & \multicolumn{4}{|c|}{ Non-OECD countries } \\
\hline & \multicolumn{2}{|c|}{ Expenditure Dec. } & \multicolumn{2}{|c|}{ Revenue Dec. } & \multicolumn{2}{|c|}{ Expenditure Dec. } & \multicolumn{2}{|c|}{ Revenue Dec. } & \multicolumn{2}{|c|}{ Expenditure Dec. } & \multicolumn{2}{|c|}{ Dec. } \\
\hline & $\begin{array}{c}\text { 1st } \\
\text { Stage }\end{array}$ & $\begin{array}{l}\text { 2nd } \\
\text { Stage }\end{array}$ & $\begin{array}{c}1 \mathrm{st} \\
\text { Stage }\end{array}$ & $\begin{array}{l}\text { 2nd } \\
\text { Stage }\end{array}$ & $\begin{array}{c}1 \mathrm{st} \\
\text { Stage }\end{array}$ & 2nd Stage & $\begin{array}{c}1 \mathrm{st} \\
\text { Stage }\end{array}$ & $\begin{array}{l}\text { 2nd } \\
\text { Stage }\end{array}$ & $\begin{array}{c}\text { 1st } \\
\text { Stage }\end{array}$ & 2nd Stage & $\begin{array}{c}\text { 1st } \\
\text { Stage }\end{array}$ & $\begin{array}{l}\text { 2nd } \\
\text { Stage }\end{array}$ \\
\hline Expenditure decentralization & & $\begin{array}{c}0.007 \\
(0.007)\end{array}$ & & & & $\begin{array}{c}0.018^{* * * *} \\
(0.006)\end{array}$ & & & & $\begin{array}{c}0.004 \\
(0.012)\end{array}$ & & \\
\hline Revenue decentralization & & & & $\begin{array}{c}0.006 \\
(0.007)\end{array}$ & & & & $\begin{array}{c}0.026 * * \\
(0.012)\end{array}$ & & & & $\begin{array}{c}0.001 \\
(0.011)\end{array}$ \\
\hline Geographic fragmentation index & $\begin{array}{c}1.26 * * * \\
(0.471)\end{array}$ & & $\begin{array}{c}1.338 * * \\
(0.596)\end{array}$ & & $\begin{array}{c}1.109 \\
(0.709)\end{array}$ & & $\begin{array}{c}0.873 \\
(0.672)\end{array}$ & & $\begin{array}{c}2.58 * * * \\
(0.372)\end{array}$ & & $\begin{array}{c}2.66 * * * \\
(0.460)\end{array}$ & \\
\hline Log country size & $\begin{array}{r}4.63 * * * \\
(1.057)\end{array}$ & & $\begin{array}{c}4.80 * * * \\
(1.243)\end{array}$ & & $\begin{array}{c}5.32 * * * \\
(1.442)\end{array}$ & & $\begin{array}{c}3.315^{* *} \\
(1.369)\end{array}$ & & $\begin{array}{c}6.07 * * * \\
(0.844)\end{array}$ & & $\begin{array}{c}6.59 * * * \\
(0.913)\end{array}$ & \\
\hline Log of initial GDP per capita & $\begin{array}{l}12.8 * * * \\
(3.252)\end{array}$ & $\begin{array}{c}-0.90 * * * \\
(0.132)\end{array}$ & $\begin{array}{c}9.263 * * \\
(3.573)\end{array}$ & $\begin{array}{c}-0.8 * * * \\
(0.132)\end{array}$ & $\begin{array}{c}14.11^{* *} \\
(6.796)\end{array}$ & $\begin{array}{c}-0.8 * * * \\
(0.285)\end{array}$ & $\begin{array}{c}20.5 * * * \\
(5.441)\end{array}$ & $\begin{array}{c}-1.31 * * * \\
(0.327)\end{array}$ & $\begin{array}{c}3.646 \\
(3.265)\end{array}$ & $\begin{array}{c}-0.57 * * * \\
(0.220)\end{array}$ & $\begin{array}{c}2.812 \\
(3.011)\end{array}$ & $\begin{array}{c}-0.520 * * \\
(0.215)\end{array}$ \\
\hline Population growth (WDI) & $\begin{array}{l}-194.25 \\
(192.0)\end{array}$ & $\begin{array}{c}-27.7 * * * \\
(9.926)\end{array}$ & $\begin{array}{c}-282.84 \\
(184.5)\end{array}$ & $\begin{array}{c}-25.89 * * \\
(10.575)\end{array}$ & $\begin{array}{l}215.210 \\
(386.72)\end{array}$ & $\begin{array}{c}17.707 \\
(14.404)\end{array}$ & $\begin{array}{l}172.451 \\
(331.89)\end{array}$ & $\begin{array}{c}14.065 \\
(12.180)\end{array}$ & $\begin{array}{c}-448^{* *} \\
(218.19)\end{array}$ & $\begin{array}{c}-25.77 * * \\
(11.898)\end{array}$ & $\begin{array}{l}-431 * * \\
(211.0)\end{array}$ & $\begin{array}{c}-23.182^{*} \\
(12.467)\end{array}$ \\
\hline Infant mortality (WDI) & $\begin{array}{l}0.112^{*} \\
(0.058)\end{array}$ & $\begin{array}{c}-0.01 * * * \\
(0.002)\end{array}$ & $\begin{array}{c}0.012 \\
(0.065)\end{array}$ & $\begin{array}{c}-0.01 * * * \\
(0.003)\end{array}$ & $\begin{array}{c}-1.9 * * * \\
(0.607)\end{array}$ & $\begin{array}{c}0.068 \\
(0.062)\end{array}$ & $\begin{array}{l}-1.324 \\
(0.867)\end{array}$ & $\begin{array}{l}-0.023 \\
(0.045)\end{array}$ & $\begin{array}{c}0.065 \\
(0.044)\end{array}$ & $\begin{array}{c}-0.01 * * * \\
(0.003)\end{array}$ & $\begin{array}{c}0.020 \\
(0.047)\end{array}$ & $\begin{array}{c}-0.008 * * \\
(0.003)\end{array}$ \\
\hline Trade openness (PWT) & $\begin{array}{c}-0.012 \\
(0.050)\end{array}$ & $\begin{array}{c}0.002 \\
(0.002)\end{array}$ & $\begin{array}{l}-0.046 \\
(0.055)\end{array}$ & $\begin{array}{c}0.003 \\
(0.002)\end{array}$ & $\begin{array}{c}0.078 \\
(0.076)\end{array}$ & $\begin{array}{c}0.002 \\
(0.003)\end{array}$ & $\begin{array}{c}-0.022 \\
(0.079)\end{array}$ & $\begin{array}{c}0.005 \\
(0.003)\end{array}$ & $\begin{array}{c}0.001 \\
(0.033)\end{array}$ & $\begin{array}{c}0.002 \\
(0.003)\end{array}$ & $\begin{array}{l}-0.003 \\
(0.039)\end{array}$ & $\begin{array}{c}0.001 \\
(0.003)\end{array}$ \\
\hline Political rights $(\mathrm{FH})$ & $\begin{array}{l}-1.085 \\
(1.127)\end{array}$ & $\begin{array}{c}0.016 \\
(0.041)\end{array}$ & $\begin{array}{c}0.037 \\
(1.276)\end{array}$ & $\begin{array}{c}0.005 \\
(0.037)\end{array}$ & $\begin{array}{c}3.70^{* * *} \\
(1.265)\end{array}$ & $\begin{array}{c}-0.27 * * \\
(0.135)\end{array}$ & $\begin{array}{c}2.447 \\
(1.742)\end{array}$ & $\begin{array}{l}-0.116 \\
(0.107)\end{array}$ & $\begin{array}{l}-0.522 \\
(0.750)\end{array}$ & $\begin{array}{l}-0.061 \\
(0.045)\end{array}$ & $\begin{array}{c}0.003 \\
(0.839)\end{array}$ & $\begin{array}{l}-0.058 \\
(0.039)\end{array}$ \\
\hline $\begin{array}{l}\text { Ethno-linguistic fractionalization } \\
\text { (AL) }\end{array}$ & $\begin{array}{c}2.191 \\
(8.221)\end{array}$ & $\begin{array}{c}0.162 \\
(0.293)\end{array}$ & $\begin{array}{c}10.399 \\
(10.734)\end{array}$ & $\begin{array}{c}0.061 \\
(0.293)\end{array}$ & $\begin{array}{l}21.27 * * \\
(8.974)\end{array}$ & $\begin{array}{r}-0.7 * * * \\
(0.259)\end{array}$ & $\begin{array}{l}32.45 * * \\
(13.050)\end{array}$ & $\begin{array}{c}-1.044 * * \\
(0.450)\end{array}$ & $\begin{array}{l}-15.18^{*} \\
(8.163)\end{array}$ & $\begin{array}{c}0.313 \\
(0.548)\end{array}$ & $\begin{array}{l}-15.97^{*} \\
(9.154)\end{array}$ & $\begin{array}{c}0.191 \\
(0.536)\end{array}$ \\
\hline Constant & $\begin{array}{l}-137 * * * \\
(32.428)\end{array}$ & $\begin{array}{l}8.63 * * * \\
(1.140)\end{array}$ & $\begin{array}{l}-109 * * * \\
(30.525)\end{array}$ & $\begin{array}{l}8.3 * * * \\
(1.150)\end{array}$ & $\begin{array}{l}-157 * * \\
(72.822)\end{array}$ & $\begin{array}{c}6.373 * * \\
(3.077)\end{array}$ & $\begin{array}{l}-210 * * * \\
(59.070)\end{array}$ & $\begin{array}{l}11.1 * * * \\
(3.044)\end{array}$ & $\begin{array}{l}-109 * * * \\
(26.107)\end{array}$ & $\begin{array}{c}6.706^{* * *} \\
(1.661)\end{array}$ & $\begin{array}{l}-103 * * * \\
(25.162)\end{array}$ & $\begin{array}{r}6.35 * * * \\
(1.677)\end{array}$ \\
\hline Regional dummies & YES & YES & YES & YES & YES & YES & YES & YES & YES & YES & YES & YES \\
\hline Time period dummies & YES & YES & YES & YES & YES & YES & YES & YES & YES & YES & YES & YES \\
\hline $\begin{array}{l}\text { Observations } \\
\text { R-squared }\end{array}$ & 236 & $\begin{array}{c}236 \\
0.256\end{array}$ & 249 & $\begin{array}{c}249 \\
0.269\end{array}$ & 124 & $\begin{array}{c}124 \\
0.406\end{array}$ & 133 & $\begin{array}{c}133 \\
0.354\end{array}$ & 112 & $\begin{array}{c}112 \\
0.378\end{array}$ & 116 & $\begin{array}{c}116 \\
0.404\end{array}$ \\
\hline
\end{tabular}

Note: Country clustered standard errors are in parentheses, stars reflect the significant levels $-* * * \mathrm{p}<0.01, * * \mathrm{p}<0.05, * \mathrm{p}<0.1$ 
Table A9. OLS estimation of the impact of fiscal decentralization on economic growth by country groups (controlling for other fiscal decentralization variable)

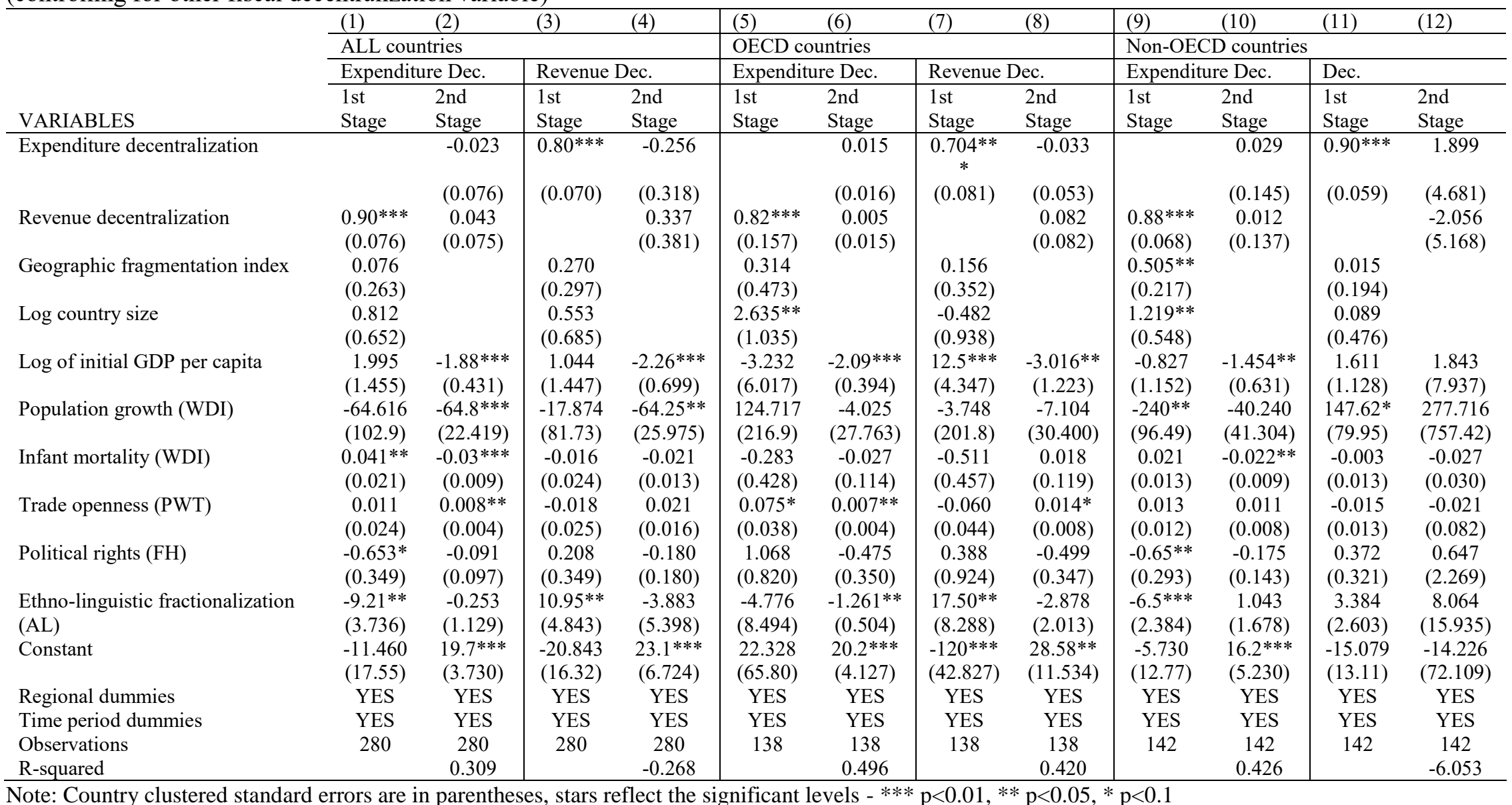


Table A10. IV OLS estimation of the impact of fiscal decentralization on economic growth by country groups (10-year averages)

\begin{tabular}{|c|c|c|c|c|c|c|c|c|c|c|c|c|}
\hline \multirow[b]{4}{*}{ VARIABLES } & $(1)$ & $(2)$ & (3) & $(4)$ & $(5)$ & $(6)$ & (7) & $(8)$ & (9) & $(10)$ & $(11)$ & $(12)$ \\
\hline & \multicolumn{4}{|c|}{ ALL countries } & \multicolumn{4}{|c|}{ OECD countries } & \multicolumn{4}{|c|}{ Non-OECD countries } \\
\hline & \multicolumn{2}{|c|}{ Expenditure Dec. } & \multicolumn{2}{|c|}{ Revenue Dec. } & \multicolumn{2}{|c|}{ Expenditure Dec. } & \multicolumn{2}{|c|}{ Revenue Dec. } & \multicolumn{2}{|c|}{ Expenditure Dec. } & \multicolumn{2}{|l|}{ Dec. } \\
\hline & 1st Stage & $\begin{array}{l}\text { 2nd } \\
\text { Stage }\end{array}$ & $\begin{array}{l}\text { 1st } \\
\text { Stage }\end{array}$ & $\begin{array}{l}\text { 2nd } \\
\text { Stage }\end{array}$ & $\begin{array}{l}\text { 1st } \\
\text { Stage }\end{array}$ & $\begin{array}{l}\text { 2nd } \\
\text { Stage }\end{array}$ & $\begin{array}{l}\text { 1st } \\
\text { Stage }\end{array}$ & $\begin{array}{l}\text { 2nd } \\
\text { Stage }\end{array}$ & 1st Stage & $\begin{array}{l}\text { 2nd } \\
\text { Stage }\end{array}$ & $\begin{array}{l}1 \text { st } \\
\text { Stage }\end{array}$ & $\begin{array}{l}\text { 2nd } \\
\text { Stage }\end{array}$ \\
\hline Expenditure decentralization & & $\begin{array}{c}0.034 \\
(0.024)\end{array}$ & & & & $\begin{array}{c}0.04^{* * *} \\
(0.012)\end{array}$ & & & & $\begin{array}{c}0.049 \\
(0.031)\end{array}$ & & \\
\hline Revenue decentralization & & & & $\begin{array}{l}0.034^{*} \\
(0.020)\end{array}$ & & & & $\begin{array}{c}0.09 * * * \\
(0.035)\end{array}$ & & & & $\begin{array}{c}0.052 * * \\
(0.024)\end{array}$ \\
\hline Geographic fragmentation index & $\begin{array}{c}1.20 * * * \\
(0.444)\end{array}$ & & $\begin{array}{c}1.39 * * * \\
(0.508)\end{array}$ & & $\begin{array}{c}0.941 \\
(0.807)\end{array}$ & & $\begin{array}{c}0.761 \\
(0.714)\end{array}$ & & $\begin{array}{c}2.21 * * * \\
(0.395)\end{array}$ & & $\begin{array}{c}2.35 * * * \\
(0.421)\end{array}$ & \\
\hline Log country size & $\begin{array}{c}4.15^{* * * *} \\
(0.924)\end{array}$ & & $\begin{array}{c}4.47 * * * \\
(0.977)\end{array}$ & & $\begin{array}{l}5.45^{* * *} \\
(1.777)\end{array}$ & & $\begin{array}{c}3.373^{* *} \\
(1.557)\end{array}$ & & $\begin{array}{c}5.02 * * * \\
(0.816)\end{array}$ & & $\begin{array}{c}6.07 * * * \\
(0.744)\end{array}$ & \\
\hline Log of initial GDP per capita & $\begin{array}{c}0.00 * * * \\
(0.000)\end{array}$ & $\begin{array}{c}-0.000^{* *} \\
(0.000)\end{array}$ & $\begin{array}{c}0.00 * * * \\
(0.000)\end{array}$ & $\begin{array}{c}-0.000^{* *} \\
(0.000)\end{array}$ & $\begin{array}{c}0.00^{* * *} \\
(0.000)\end{array}$ & $\begin{array}{c}-0.00 * * \\
(0.000)\end{array}$ & $\begin{array}{c}0.00^{* * *} \\
(0.000)\end{array}$ & $\begin{array}{c}-0.00 * * \\
(0.000)\end{array}$ & $\begin{array}{c}0.00 * * * \\
(0.000)\end{array}$ & $\begin{array}{c}-0.000^{*} \\
(0.000)\end{array}$ & $\begin{array}{c}0.00 * * * \\
(0.000)\end{array}$ & $\begin{array}{c}-0.000^{* *} \\
(0.000)\end{array}$ \\
\hline Population growth (WDI) & $\begin{array}{l}-5612 * * * \\
(176.991)\end{array}$ & $\begin{array}{l}-23.416 \\
(33.598)\end{array}$ & $\begin{array}{c}-535 * * * \\
(173.95)\end{array}$ & $\begin{array}{l}-38.106 \\
(25.644)\end{array}$ & $\begin{array}{r}232.107 \\
(534.3)\end{array}$ & $\begin{array}{l}50.516^{*} \\
(27.904)\end{array}$ & $\begin{array}{l}84.365 \\
(455.6)\end{array}$ & $\begin{array}{l}77.588^{*} \\
(44.148)\end{array}$ & $\begin{array}{l}-573 * * * \\
(162.84)\end{array}$ & $\begin{array}{l}-42.080 \\
(37.592)\end{array}$ & $\begin{array}{l}-527 * * \\
(207.07)\end{array}$ & $\begin{array}{c}-64.90 * * \\
(26.740)\end{array}$ \\
\hline Infant mortality (WDI) & $\begin{array}{c}0.054 \\
(0.063)\end{array}$ & $\begin{array}{c}-0.02 * * * \\
(0.007)\end{array}$ & $\begin{array}{l}-0.010 \\
(0.058)\end{array}$ & $\begin{array}{c}-0.02 * * * \\
(0.006)\end{array}$ & $\begin{array}{c}-0.78 * * \\
(0.372)\end{array}$ & $\begin{array}{c}0.19 * * * \\
(0.034)\end{array}$ & $\begin{array}{c}-0.78 * * \\
(0.359)\end{array}$ & $\begin{array}{c}0.24 * * * \\
(0.053)\end{array}$ & $\begin{array}{c}0.102 * * \\
(0.050)\end{array}$ & $\begin{array}{c}-0.02 * * * \\
(0.007)\end{array}$ & $\begin{array}{c}0.026 \\
(0.058)\end{array}$ & $\begin{array}{c}-0.02 * * * \\
(0.006)\end{array}$ \\
\hline Trade openness (PWT) & $\begin{array}{l}-0.010 \\
(0.046)\end{array}$ & $\begin{array}{c}0.010^{* *} \\
(0.005)\end{array}$ & $\begin{array}{l}-0.009 \\
(0.049)\end{array}$ & $\begin{array}{c}0.009^{* *} \\
(0.005)\end{array}$ & $\begin{array}{c}0.061 \\
(0.074)\end{array}$ & $\begin{array}{c}0.01 * * * \\
(0.003)\end{array}$ & $\begin{array}{l}-0.015 \\
(0.072)\end{array}$ & $\begin{array}{c}0.02 * * * \\
(0.004)\end{array}$ & $\begin{array}{c}0.009 \\
(0.036)\end{array}$ & $\begin{array}{l}0.012^{*} \\
(0.007)\end{array}$ & $\begin{array}{c}0.022 \\
(0.041)\end{array}$ & $\begin{array}{c}0.010 \\
(0.007)\end{array}$ \\
\hline Political rights $(\mathrm{FH})$ & $\begin{array}{c}-1.496^{*} \\
(0.902)\end{array}$ & $\begin{array}{c}0.100 \\
(0.135)\end{array}$ & $\begin{array}{l}-0.104 \\
(1.167)\end{array}$ & $\begin{array}{c}0.208 \\
(0.136)\end{array}$ & $\begin{array}{c}2.328 * * \\
(0.928)\end{array}$ & $\begin{array}{c}-0.69 * * \\
(0.294)\end{array}$ & $\begin{array}{c}1.806 \\
(1.130)\end{array}$ & $\begin{array}{l}-0.464 \\
(0.363)\end{array}$ & $\begin{array}{l}-0.817 \\
(0.926)\end{array}$ & $\begin{array}{l}-0.140 \\
(0.187)\end{array}$ & $\begin{array}{c}-0.295 \\
(1.199)\end{array}$ & $\begin{array}{c}0.012 \\
(0.167)\end{array}$ \\
\hline $\begin{array}{l}\text { Ethno-linguistic fractionalization } \\
\text { (AL) }\end{array}$ & $\begin{array}{l}3.048 \\
(7.861)\end{array}$ & $\begin{array}{l}-0.484 \\
(0.777)\end{array}$ & $\begin{array}{c}7.978 \\
(9.996)\end{array}$ & $\begin{array}{l}-1.070 \\
(0.745)\end{array}$ & $\begin{array}{l}18.70 * * \\
(9.192)\end{array}$ & $\begin{array}{l}-1.4 * * * \\
(0.493)\end{array}$ & $\begin{array}{r}29.16^{* *} \\
(11.60)\end{array}$ & $\begin{array}{r}-3.30 * * \\
(1.398)\end{array}$ & $\begin{array}{l}-13.724 \\
(8.472)\end{array}$ & $\begin{array}{c}0.102 \\
(1.340)\end{array}$ & $\begin{array}{l}-13.478 \\
(10.188)\end{array}$ & $\begin{array}{l}-0.460 \\
(1.208)\end{array}$ \\
\hline Constant & $\begin{array}{l}-30.284 \\
(19.283)\end{array}$ & $\begin{array}{r}2.52^{* * * *} \\
(0.579)\end{array}$ & $\begin{array}{l}-44.9 * * \\
(20.633)\end{array}$ & $\begin{array}{r}2.81 * * * \\
(0.616)\end{array}$ & $\begin{array}{l}-41.440 \\
(44.02)\end{array}$ & $\begin{array}{l}0.795 \\
(0.614)\end{array}$ & $\begin{array}{l}-42.741 \\
(37.57)\end{array}$ & $\begin{array}{l}1.032 \\
(1.396)\end{array}$ & $\begin{array}{l}-69.7 * * * \\
(17.087)\end{array}$ & $\begin{array}{r}3.82 * * * \\
(0.933)\end{array}$ & $\begin{array}{c}-75^{* * *} \\
(19.251)\end{array}$ & $\begin{array}{r}3.69 * * * \\
(0.970)\end{array}$ \\
\hline Regional dummies & YES & YES & YES & YES & YES & YES & YES & YES & YES & YES & YES & YES \\
\hline Time period dummies & YES & YES & YES & YES & YES & YES & YES & YES & YES & YES & YES & YES \\
\hline Observations & 150 & 150 & 156 & 156 & 69 & 69 & 72 & 72 & 81 & 81 & 84 & 84 \\
\hline R-squared & & 0.362 & & 0.441 & & 0.418 & & 0.274 & & 0.495 & & 0.574 \\
\hline
\end{tabular}


Table A11. IV OLS estimation of the impact of fiscal decentralization on economic growth by country groups (Only GFI as an IV)

\begin{tabular}{|c|c|c|c|c|c|c|c|c|c|c|c|c|}
\hline \multirow[b]{4}{*}{ VARIABLES } & (1) & $(2)$ & (3) & (4) & (5) & $(6)$ & $(7)$ & $(8)$ & (9) & $(10)$ & $(11)$ & $(12)$ \\
\hline & \multicolumn{4}{|c|}{ ALL countries } & \multicolumn{4}{|c|}{ OECD countries } & \multicolumn{4}{|c|}{ Non-OECD countries } \\
\hline & \multicolumn{2}{|c|}{ Expenditure Dec. } & \multicolumn{2}{|c|}{ Revenue Dec. } & \multicolumn{2}{|c|}{ Expenditure Dec. } & \multicolumn{2}{|c|}{ Revenue Dec. } & \multicolumn{2}{|c|}{ Expenditure Dec. } & \multicolumn{2}{|c|}{ Dec. } \\
\hline & 1st Stage & $\begin{array}{c}\text { 2nd } \\
\text { Stage }\end{array}$ & 1st Stage & $\begin{array}{c}\text { 2nd } \\
\text { Stage }\end{array}$ & 1st Stage & $\begin{array}{c}\text { 2nd } \\
\text { Stage }\end{array}$ & 1st Stage & $\begin{array}{c}\text { 2nd } \\
\text { Stage }\end{array}$ & 1st Stage & $\begin{array}{c}\text { 2nd } \\
\text { Stage }\end{array}$ & 1st Stage & $\begin{array}{c}\text { 2nd } \\
\text { Stage }\end{array}$ \\
\hline Expenditure decentralization & & $\begin{array}{l}-0.090 \\
(0.081)\end{array}$ & & & & $\begin{array}{l}-0.051 \\
(0.052)\end{array}$ & & & & $\begin{array}{c}0.124 \\
(0.125)\end{array}$ & & \\
\hline Revenue decentralization & & & & $\begin{array}{l}-0.122 \\
(0.117)\end{array}$ & & & & $\begin{array}{l}-0.176 \\
(0.678)\end{array}$ & & & & $\begin{array}{c}0.384 \\
(0.487)\end{array}$ \\
\hline $\begin{array}{l}\text { Geographic fragmentation } \\
\text { index }\end{array}$ & $\begin{array}{l}-0.296 \\
(0.187)\end{array}$ & & $\begin{array}{l}-0.276 \\
(0.211)\end{array}$ & & $\begin{array}{l}-0.411 \\
(0.349)\end{array}$ & & $\begin{array}{l}-0.100 \\
(0.398)\end{array}$ & & $\begin{array}{c}0.261 \\
(0.234)\end{array}$ & & $\begin{array}{c}0.175 \\
(0.268)\end{array}$ & \\
\hline Log of initial GDP per capita & $\begin{array}{c}14.307 * * \\
* \\
(3.499)\end{array}$ & $\begin{array}{l}-0.384 \\
(1.240)\end{array}$ & $\begin{array}{c}10.387 * * \\
* \\
(3.747)\end{array}$ & $\begin{array}{l}-0.455 \\
(1.361)\end{array}$ & $\begin{array}{c}20.220 * * \\
(9.246)\end{array}$ & $\begin{array}{l}-0.437 \\
(1.426)\end{array}$ & $\begin{array}{c}23.16^{* * * *} \\
(6.129)\end{array}$ & $\begin{array}{c}1.972 \\
(15.992)\end{array}$ & $\begin{array}{l}7.835^{*} \\
(4.466)\end{array}$ & $\begin{array}{l}-2.217^{*} \\
(1.239)\end{array}$ & $\begin{array}{l}7.636^{* *} \\
(3.818)\end{array}$ & $\begin{array}{l}-4.120 \\
(3.968)\end{array}$ \\
\hline Population growth (WDI) & $\begin{array}{l}-117.507 \\
(183.535)\end{array}$ & $\begin{array}{l}-74.7 * * * \\
(26.375)\end{array}$ & $\begin{array}{l}-211.384 \\
(180.009)\end{array}$ & $\begin{array}{l}-95.67 * * \\
(48.219)\end{array}$ & $\begin{array}{l}-157.960 \\
(488.346)\end{array}$ & $\begin{array}{l}-16.511 \\
(34.793)\end{array}$ & $\begin{array}{l}-72.516 \\
(394.024)\end{array}$ & $\begin{array}{l}-13.666 \\
(92.153)\end{array}$ & $\begin{array}{l}-24.907 \\
(241.923)\end{array}$ & $\begin{array}{l}-38.575 \\
(38.703)\end{array}$ & $\begin{array}{c}4.341 \\
(236.753)\end{array}$ & $\begin{array}{l}-44.726 \\
(76.538)\end{array}$ \\
\hline Infant mortality (WDI) & $\begin{array}{c}0.153 * * * \\
(0.055)\end{array}$ & $\begin{array}{l}-0.011 \\
(0.018)\end{array}$ & $\begin{array}{c}0.056 \\
(0.066)\end{array}$ & $\begin{array}{l}-0.018 \\
(0.017)\end{array}$ & $\begin{array}{c}-2.61 * * * \\
(0.783)\end{array}$ & $\begin{array}{l}-0.216 \\
(0.184)\end{array}$ & $\begin{array}{c}-1.763 * * \\
(0.854)\end{array}$ & $\begin{array}{l}-0.502 \\
(1.224)\end{array}$ & $\begin{array}{c}0.142 * * * \\
(0.050)\end{array}$ & $\begin{array}{l}-0.035^{*} \\
(0.020)\end{array}$ & $\begin{array}{l}0.114 * * \\
(0.048)\end{array}$ & $\begin{array}{l}-0.056 \\
(0.055)\end{array}$ \\
\hline Trade openness (PWT) & $\begin{array}{c}- \\
0.136^{* * *} * \\
(0.038)\end{array}$ & -0.004 & $\begin{array}{c}- \\
0.174 * * * \\
(0.038)\end{array}$ & $\begin{array}{l}-0.014 \\
(0.019)\end{array}$ & $\begin{array}{l}-0.046 \\
(0.081)\end{array}$ & $\begin{array}{c}0.007 \\
(0.007)\end{array}$ & $\begin{array}{l}-0.087 \\
(0.065)\end{array}$ & $\begin{array}{l}-0.006 \\
(0.054)\end{array}$ & $\begin{array}{c}-0.19^{* * *} \\
(0.053)\end{array}$ & $\begin{array}{c}0.028 \\
(0.027)\end{array}$ & $\begin{array}{c}-0.22 * * * \\
(0.053)\end{array}$ & $\begin{array}{l}0.089 \\
(0.113)\end{array}$ \\
\hline Political rights $(\mathrm{FH})$ & $\begin{array}{l}-0.921 \\
(1.184)\end{array}$ & $\begin{array}{l}-0.212 \\
(0.175)\end{array}$ & $\begin{array}{c}0.314 \\
(1.446)\end{array}$ & $\begin{array}{l}-0.012 \\
(0.251)\end{array}$ & $\begin{array}{c}4.195 * * \\
(1.775)\end{array}$ & $\begin{array}{l}-0.147 \\
(0.414)\end{array}$ & $\begin{array}{c}2.572 \\
(1.814)\end{array}$ & $\begin{array}{c}0.324 \\
(1.873)\end{array}$ & $\begin{array}{c}0.097 \\
(1.053)\end{array}$ & $\begin{array}{l}-0.234^{*} \\
(0.137)\end{array}$ & $\begin{array}{c}1.189 \\
(1.225)\end{array}$ & $\begin{array}{l}-0.564 \\
(0.661)\end{array}$ \\
\hline $\begin{array}{l}\text { Ethno-linguistic } \\
\text { fractionalization (AL) }\end{array}$ & $\begin{array}{c}7.351 \\
(9.087)\end{array}$ & $\begin{array}{c}0.698 \\
(1.002)\end{array}$ & $\begin{array}{l}16.436 \\
(10.144)\end{array}$ & $\begin{array}{c}1.624 \\
(1.651)\end{array}$ & $\begin{array}{l}23.427 * \\
(13.879)\end{array}$ & $\begin{array}{c}0.270 \\
(1.551)\end{array}$ & $\begin{array}{c}35.04 * * * \\
(13.222)\end{array}$ & $\begin{array}{c}5.582 \\
(23.531)\end{array}$ & $\begin{array}{l}-13.568 \\
(11.816)\end{array}$ & $\begin{array}{c}1.800 \\
(1.893)\end{array}$ & $\begin{array}{l}-14.940 \\
(11.948)\end{array}$ & $\begin{array}{c}4.879 \\
(6.702)\end{array}$ \\
\hline Constant & $\begin{array}{c}- \\
83.47 * * * \\
(31.795)\end{array}$ & $\begin{array}{r}9.576 \\
(8.899)\end{array}$ & $\begin{array}{l}-52.769 \\
(35.472)\end{array}$ & $\begin{array}{r}11.068 \\
(9.741)\end{array}$ & $\begin{array}{l}-136.523 \\
(95.915)\end{array}$ & $\begin{array}{c}7.228 \\
(12.490)\end{array}$ & $\begin{array}{l}-188 . * * * \\
(67.727)\end{array}$ & $\begin{array}{l}-12.627 \\
(133.48)\end{array}$ & $\begin{array}{l}-50.824 \\
(34.884)\end{array}$ & $\begin{array}{l}20.7 * * * \\
(7.989)\end{array}$ & $\begin{array}{l}-45.171 \\
(31.867)\end{array}$ & $\begin{array}{c}29.941 \\
(21.769)\end{array}$ \\
\hline Regional dummies & YES & YES & YES & YES & YES & YES & YES & YES & YES & YES & YES & YES \\
\hline Time period dummies & YES & YES & YES & YES & YES & YES & YES & YES & YES & YES & YES & YES \\
\hline Observations & 285 & 285 & 301 & 301 & 138 & 138 & 147 & 147 & 147 & 147 & 154 & 154 \\
\hline R-squared & & -0.032 & & -0.193 & & 0.280 & & -0.491 & & 0.325 & & -0.885 \\
\hline
\end{tabular}

Note: Country clustered standard errors are in parentheses, stars reflect the significant levels $-* * * p<0.01, * * p<0.05, * p<0.1$ 
Table A12. IV OLS estimation of the impact of fiscal decentralization on economic growth by country groups (only log country size as an IV)

\begin{tabular}{|c|c|c|c|c|c|c|c|c|c|c|c|c|}
\hline \multirow[b]{4}{*}{ VARIABLES } & (1) & $(2)$ & (3) & (4) & $(5)$ & $(6)$ & $(7)$ & (8) & (9) & $(10)$ & $(11)$ & (12) \\
\hline & \multicolumn{4}{|c|}{ ALL countries } & \multicolumn{4}{|c|}{ OECD countries } & \multicolumn{4}{|c|}{ Non-OECD countries } \\
\hline & \multicolumn{2}{|c|}{ Expenditure Dec. } & \multicolumn{2}{|c|}{ Revenue Dec. } & \multicolumn{2}{|c|}{ Expenditure Dec. } & \multicolumn{2}{|c|}{ Revenue Dec. } & \multicolumn{2}{|c|}{ Expenditure Dec. } & \multicolumn{2}{|c|}{ Dec. } \\
\hline & 1st Stage & 2nd Stage & 1st Stage & 2nd Stage & 1st Stage & 2nd Stage & 1st Stage & 2nd Stage & 1st Stage & 2nd Stage & 1st Stage & 2nd Stage \\
\hline Expenditure decentralization & & $\begin{array}{c}0.010 \\
(0.019)\end{array}$ & & & & $\begin{array}{c}0.010 \\
(0.011)\end{array}$ & & & & $\begin{array}{l}-0.013 \\
(0.087)\end{array}$ & & \\
\hline Revenue decentralization & & & & $\begin{array}{c}0.007 \\
(0.021)\end{array}$ & & & & $\begin{array}{l}0.025 \\
(0.023)\end{array}$ & & & & $\begin{array}{l}-0.062 \\
(0.078)\end{array}$ \\
\hline Log country size & $\begin{array}{c}1.986^{* * *} \\
(0.511)\end{array}$ & & $\begin{array}{c}2.092 * * * \\
(0.519)\end{array}$ & & $\begin{array}{c}3.109 * * * \\
(1.074)\end{array}$ & & $\begin{array}{c}1.633 \\
(1.217)\end{array}$ & & $\begin{array}{c}0.724 \\
(0.577)\end{array}$ & & $\begin{array}{l}1.181 * \\
(0.605)\end{array}$ & \\
\hline Log of initial GDP per capita & $\begin{array}{c}12.23 * * * \\
(3.407)\end{array}$ & $\begin{array}{c}- \\
1.886^{* * *} \\
(0.477)\end{array}$ & $\begin{array}{l}8.062 * * \\
(3.738)\end{array}$ & $\begin{array}{c}- \\
1.900 * * * \\
(0.472)\end{array}$ & $\begin{array}{l}15.088^{*} \\
(7.920)\end{array}$ & $\begin{array}{c}- \\
1.827 * * * \\
(0.337)\end{array}$ & $\begin{array}{c}20.29 * * * \\
(5.739)\end{array}$ & $\begin{array}{c}- \\
2.814 * * * \\
(0.468)\end{array}$ & $\begin{array}{l}8.226 * * \\
(4.148)\end{array}$ & $\begin{array}{l}-1.079 \\
(0.956)\end{array}$ & $\begin{array}{l}7.487 * * \\
(3.535)\end{array}$ & $\begin{array}{l}-0.613 \\
(0.938)\end{array}$ \\
\hline Population growth (WDI) & $\begin{array}{l}-185.038 \\
(185.763)\end{array}$ & $\begin{array}{c}- \\
62.64 * * * \\
(23.066)\end{array}$ & $\begin{array}{l}-263.759 \\
(161.445)\end{array}$ & $\begin{array}{c}- \\
68.39 * * * \\
(26.088)\end{array}$ & $\begin{array}{l}130.632 \\
(372.06)\end{array}$ & $\begin{array}{l}-5.449 \\
(27.350)\end{array}$ & $\begin{array}{c}90.310 \\
(348.999)\end{array}$ & $\begin{array}{c}2.167 \\
(23.134)\end{array}$ & $\begin{array}{l}-61.219 \\
(246.44)\end{array}$ & $\begin{array}{l}-40.416 \\
(32.293)\end{array}$ & $\begin{array}{l}-54.852 \\
(223.929)\end{array}$ & $\begin{array}{l}-39.952 \\
(44.595)\end{array}$ \\
\hline Infant mortality (WDI) & $\begin{array}{l}0.108^{*} \\
(0.063)\end{array}$ & $\begin{array}{c}0.029^{* * *} \\
(0.009)\end{array}$ & 0.009 & $\begin{array}{c}0.028^{* * *} \\
(0.008)\end{array}$ & $\begin{array}{c}-1.96 * * * \\
(0.679)\end{array}$ & $\begin{array}{l}-0.053 \\
(0.120)\end{array}$ & $\begin{array}{l}-1.440 * \\
(0.813)\end{array}$ & $\begin{array}{l}-0.143 \\
(0.099)\end{array}$ & $\begin{array}{l}0.111^{*} \\
(0.059)\end{array}$ & $\begin{array}{l}-0.017 \\
(0.016)\end{array}$ & $\begin{array}{c}0.070 \\
(0.061)\end{array}$ & $\begin{array}{l}-0.010 \\
(0.015)\end{array}$ \\
\hline Trade openness (PWT) & $\begin{array}{c}-0.11 * * * \\
(0.035)\end{array}$ & $\begin{array}{l}0.007^{*} \\
(0.004)\end{array}$ & $\begin{array}{c}-0.15 * * * \\
(0.035)\end{array}$ & $\begin{array}{l}0.005 \\
(0.004)\end{array}$ & $\begin{array}{l}-0.034 \\
(0.064)\end{array}$ & $\begin{array}{l}0.007^{*} \\
(0.004)\end{array}$ & $\begin{array}{l}-0.095^{*} \\
(0.056)\end{array}$ & $\begin{array}{c}0.009 * * * \\
(0.003)\end{array}$ & $\begin{array}{l}-0.2 * * * \\
(0.052)\end{array}$ & $\begin{array}{l}-0.001 \\
(0.022)\end{array}$ & $\begin{array}{c}-0.23 * * * \\
(0.055)\end{array}$ & $\begin{array}{l}-0.016 \\
(0.022)\end{array}$ \\
\hline Political rights $(\mathrm{FH})$ & $\begin{array}{l}-0.981 \\
(1.078)\end{array}$ & $\begin{array}{l}-0.106 \\
(0.098)\end{array}$ & $\begin{array}{c}0.023 \\
(1.311)\end{array}$ & $\begin{array}{l}-0.043 \\
(0.101)\end{array}$ & $\begin{array}{l}3.092 * * \\
(1.444)\end{array}$ & $\begin{array}{l}-0.432 \\
(0.354)\end{array}$ & $\begin{array}{c}1.863 \\
(1.618)\end{array}$ & $\begin{array}{l}-0.221 \\
(0.285)\end{array}$ & $\begin{array}{c}0.045 \\
(1.075)\end{array}$ & $\begin{array}{l}-0.213 \\
(0.166)\end{array}$ & $\begin{array}{c}0.844 \\
(1.303)\end{array}$ & $\begin{array}{l}-0.034 \\
(0.237)\end{array}$ \\
\hline $\begin{array}{l}\text { Ethno-linguistic } \\
\text { fractionalization (AL) }\end{array}$ & $\begin{array}{c}8.306 \\
(8.276)\end{array}$ & $\begin{array}{l}0.225 \\
(0.576)\end{array}$ & $\begin{array}{l}16.646^{*} \\
(8.971)\end{array}$ & $\begin{array}{l}-0.244 \\
(0.579)\end{array}$ & $\begin{array}{l}26.006^{* *} \\
(11.565)\end{array}$ & $\begin{array}{c}-0.974^{* *} \\
(0.415)\end{array}$ & $\begin{array}{c}37.16^{* * *} \\
(11.854)\end{array}$ & $\begin{array}{l}-1.355^{*} \\
(0.797)\end{array}$ & $\begin{array}{c}-8.907 \\
(10.776)\end{array}$ & $\begin{array}{c}0.281 \\
(2.261)\end{array}$ & $\begin{array}{l}-11.558 \\
(11.444)\end{array}$ & $\begin{array}{l}-1.338 \\
(2.705)\end{array}$ \\
\hline Constant & $\begin{array}{l}-77.74 * * \\
(32.567)\end{array}$ & $\begin{array}{c}19.741 * * \\
* \\
(4.091)\end{array}$ & $\begin{array}{l}-43.100 \\
(36.156)\end{array}$ & $\begin{array}{c}20.334 * * \\
* \\
(4.095)\end{array}$ & $\begin{array}{l}-116.302 \\
(77.657)\end{array}$ & $\begin{array}{c}18.08^{* * *} \\
(3.536)\end{array}$ & $\begin{array}{l}-171^{* * *} \\
(58.912)\end{array}$ & $\begin{array}{c}27.254^{* *} \\
* \\
(4.127)\end{array}$ & $\begin{array}{l}-41.560 \\
(35.121)\end{array}$ & $\begin{array}{l}14.77 * * \\
(6.090)\end{array}$ & $\begin{array}{l}-31.892 \\
(31.543)\end{array}$ & $\begin{array}{l}12.649^{*} \\
(6.561)\end{array}$ \\
\hline Regional dummies & YES & YES & YES & YES & YES & YES & YES & YES & YES & YES & YES & YES \\
\hline Time period dummies & YES & YES & YES & YES & YES & YES & YES & YES & YES & YES & YES & YES \\
\hline $\begin{array}{l}\text { Observations } \\
\text { R-squared }\end{array}$ & 285 & $\begin{array}{c}285 \\
0.312\end{array}$ & 301 & $\begin{array}{c}301 \\
0.376\end{array}$ & 138 & $\begin{array}{c}138 \\
0.491\end{array}$ & 147 & $\begin{array}{c}147 \\
0.510\end{array}$ & 147 & $\begin{array}{c}147 \\
0.370\end{array}$ & 154 & $\begin{array}{c}154 \\
0.342\end{array}$ \\
\hline
\end{tabular}

